\title{
CONTRIBUTIONS TO THE ZOOLOGY OF NEW
}

\section{GUINEA.}

\section{Parts I AND II.}

By E. P. Ramsay, F.L.S., Curator of the Australian Museum, Sydney.

Containing a list of the Mammals (part I) and Birds (part II) obtained during Mr. Goldie's second Expedition to New Guinea, collected by Mr. Goldie, the leader of the Expedition, and Mr. Alex. Morton, a collector from the Australian Museum, with descriptions of some new birds recently forwarded to the Museum by $\mathrm{Mr}$. Kendal Broadbent, from the same localities.

In May, 1877, the Trustees of the Australian Museum despatched one of their collectors, Mr. Alexander Morton, to New Guinea; an opportunity having offered for him to accompany Mr. Andrew Goldie, who was starting to explore the South Eastern portion of that great island, on behalf of R. B. Williams, Esq., of Holloway Place, London.

The following notes, then, are on the collections made by Morton, and most of the remarks on the localities and habits of the birds are from his note book.

Mr. Goldie has also very liberally placed at my disposal the very large collections of mammals, birds, and reptiles made by himself and his collectors, Messrs. Shaw and Blunden, which is without doubt the largest collection of Natural History and Ethnological specimens yet made in those parts.

Mr. Ingham and Mr. Kendal Broadbent have also been collecting on the South East Coast, and as a portion of their collections has been forwarded to me, I am enabled to enumerate a few additional species; a full account of this collection will be given in another paper.

Mr. Goldie's collection is by far the most important yet made on the South East Coast; and although not containing many new species, yet from the large number of specimens which it contains, 
I am enabled to throw some light on the distribution of the species in that district; and in this respect, I have also found Morton's notes of great interest as to localities, and other details respecting the habits of the birds in his collection.

Mr. K. Broadbent, having succeeded in getting a considerable distance inland, enables me to add some important new species to the list; the total number of birds examined amount to about 2,500 .

Very few fishes, and only two or three reptiles were obtained; amongst the latter, only one, which I believe to be new, a fresh water tortoise belonging to the genus Chelodina.

The fishes, reptiles, and remarks on the Ethnological collection, which is very extensive, I shall have for another paper. The first part of the present communication contains a list with remarks on the mammals, the second is devoted to the birds.

\section{PART. 1. MAMMALS.}

\section{1.-Sus papuensis, Gray.}

The wild Pig is quite distinct from those now usually kept in domestication by the natives, but the young are sometimes caught, and when tamed, allowed to run about the villages. They are longitudinally striped with brownish yellow.

\section{2.-Canis Familiaris, var. Papuensis.}

The dogs used by the natives are of various colors, usually yellowish with short ears, and small brushy tail. They have the peculiarity of being unable to bark, properly so-called; but this deficiency is fully compensated by the propensity of uttering a most dismal howling at most inappropriate times. The specimen sent down by Mr. Goldie in spirits unfortunately arrived in a very bad state, but Mr. Morton and Mr. Broadbent inform me that the usual height is about 12 to 15 inches.

\section{3.-Pteropus conspicillatus, Gould.}

This species is apparently common towards South Cape and at Coutance Island, frequenting the fig trees, on the fruit of which they usually feed.-(Goldie, Morton, Broadbent). 


\section{4.-Rhinolophus $s p$.}

One specimen only, not in good state, and which I have been as yet unable to determine. (Mr. Goldie's collection).

\section{5.-Scotophilus nigrogriseus, Gould.}

One specimen obtained by Broadbent, which does not appear to me to differ from the Australian examples.

$$
\text { 6.-TAPHOZOUs, } s p \text {. }
$$

Specimens from Broadbent's collection. Under surface ashy white, back brown, wings and face black, otherwise the same as the Cape York examples, from which it may prove to be specifically different.

\section{7.-Harpya cephalotes, Pallas.}

One specimen, obtained by Broadbent, at Heath Island. Is slightly different from the Cape York specimens, and also from those (H. major, Dob.) from the Duke of York group.

\section{8.-Belideus ariel, Gould.}

The Port Moresby specimens differ only slightly in the tint of colouring in the fur, being slightly more yellowish than the N. S. Wales examples. This species is closely allied to, if not identical with Belideus breviceps, Waterhouse. (Goldie, Broadbent).

\section{9.-Cuscus orientalis.}

This species was not obtained in the immediate neighbourhood of Port Moresby, but some miles inland. Several specimens were collected by Mr. Goldie during his trip to the South East, where they seem to be the common species. I find no material difference between these specimens and those from the Duke of York Islands, collected by the Rev. George Brown, of which the Museum possesses a large series. Morton and Broadbent obtained it on the Laloki River.

\section{0.-CUSCUS CHRYSORRHOUS var. GOLDIEI.}

Mr. Goldie has sent a very fine pair of this, perhaps the largest species known-a description of the female of which I have given in the P.L.S. of N.S.W., vol. I., p. 395. 
The male resembles that sex of $C$. maculata from Cape York, and is largely marked with irregular white blotches on a dull brown ground. The feet, face, and rump are rusty red or of a yellowish rust colour, in some darker than in others. A waxy secretion near the testes is collected by the natives, and being rolled up with the leaves of a species of Salvia is kept as a scent bag, and worn about the person. Broadbent obtained a fine series of this species about 30 miles inland from Port Moresby.

11.-Macropus crassipes, Ramsay, P.L.S., N.S.W., vol. I, p. 162

This is the common species about Port Moresby.

(Goldie, Morton, Broadbent)

12.-Dendrogalus, $s p$.

A species of Dendrogalus was met with upon two occasions, but only one specimen has been obtained, which is, I believe, in Mr. Goldie's collection.

Loc., East Cape, Blunden and Goldie. Goldie River, Broadbent.

13.-Perameles moresbiensis, Ramsay, P.L.S., N.S.W., Vol. 2 p. 14.

One large specimen in Morton's collection measures:Total length to root of tail, 15 in.; from snout to ear, 3.2 in.; to eye, 1.35 ; fore foot and toes, 1.6 ; hind foot and toes, 1.6 ; tail, 6 in. One young one in spirits obtained by Broadbent is of apparently the same species.

Loc., Port Moresby, Laloki River, Goldie River, \&c. *

14.--Echidna (Tachyglossus) LaWesi. Ramsay, P.L.S., N.S.W., Vol. 2 p. 32

Mr. Goldie was fortunate enough to obtain from the natives three specimens, but unfortunately preserved only the stuffed skins, so that I have no opportunity of adding any further information than that contained in my previous paper. The natives look upon them as a most delicious article of food.

* I may as well indicate here the discovery by Mr. K. Broadbent of a very large species of Perameles? in the mountains adjacent to the Goldie River. This animal, which will probably form the type of a new genus, will be described hereafter. 


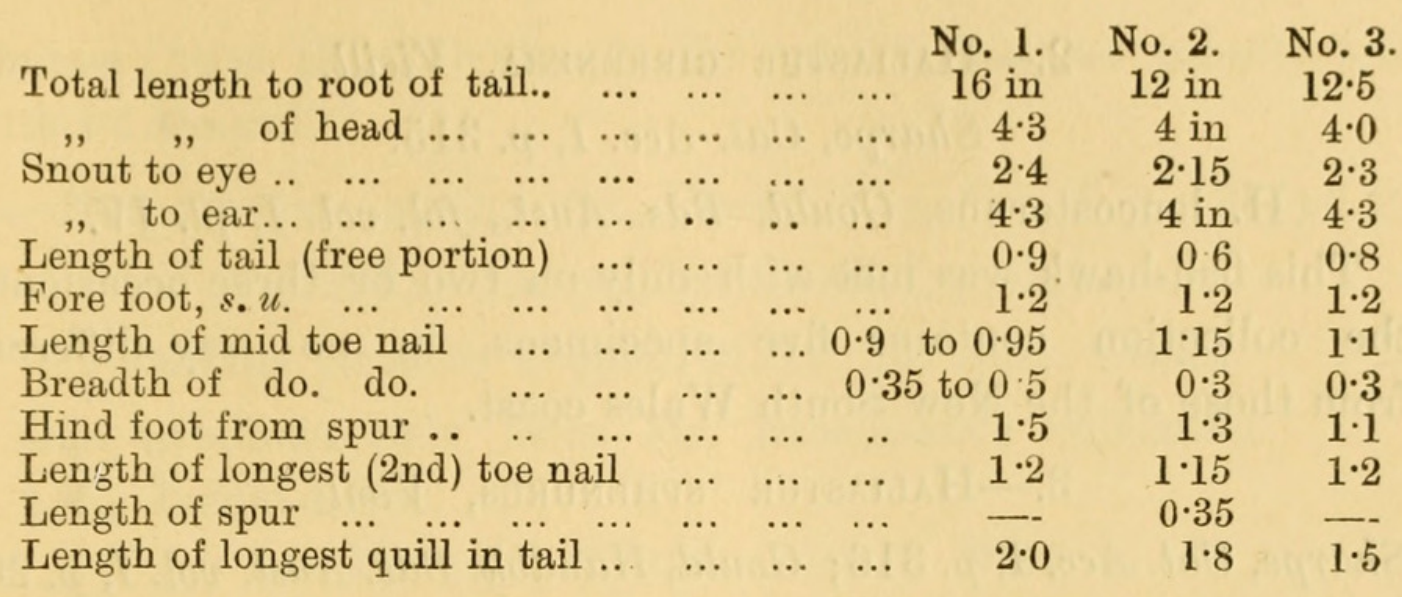

\section{PART II. -AVES.}

The works referred to in this paper are Count Salvadori's numerous ornithological contributions to the Anmali del Museo Civico di St. Nat. di Genova, also his Prodromus Ornithologice Papuasice et Moluccarum, I. to V.; Mr. R. B. Sharpe's Contributions to the Ornithology of New Guinecr, Papers I, II, and III, in the Journal of the Linnean Society, Zoology, vol. XIII; and I have also referred to some former papers of my own on the same subject, published in previous numbers of this Society's Proceedings.

I find, of the 200 species here enumerated, 78 of them are also indigenous to Australia, and, if we add the Australian species from the lists of birds obtained by Signor D'Albertis, and by the Macleay Expedition, we find the number common to the Australian and South East coast of New Guinea, to be 143 species.

\section{ACCIPITRES.}

\section{FALCONID $\nRightarrow$.}

\section{1.-Haliaetus leucogaster, $G m$.}

Sharpe, Cat. Acc. I, p. 307 ; Gould, Bds. Aust. fol. vol. I, pl. 3.

This fine sea-eagle was met with occasionally on the coast. On one occasion Mr. Goldie was fortunate enough to obtain its eggs from an immense nest, composed of about a cartload of sticks and placed on a rocky islet near the coast; a fine adult bird in full plumage was obtained by Broadbent. 
2.-Haliastur girrenera, Vieill.

Sharpe, Cat. Acc. I, p. 315.

H. leucosternus, Gould, Bds. Aust., fol. vol. I, pl. IV.

This fish-hawk was met with only on two or three occasions; the collection contains five specimens, in no way different from those of the New South Wales coast.

\section{3.-Haliastur sphenurus, Vieill.}

Sharpe, Cat. Acc. I, p. 316; Gould, Handble. Bds. Aust. vol. I, p. 20.

Common at Port Moresby, and all along the coast.

$$
\text { 4.-Baza reinwardtit, Mull. and Schleg. }
$$

Sharpe, Journ. Linn. Soc. Zool. XIII, p. 490 ; id. Cat. B. I, p. 359.

B. stenozoa; Ramsay, P. T. Soc. N.S.W., vol. I, p. 387.

One very fine adult male from Broadbent's collection, shot inland on the Laloki River; it agrees with Mr. Sharpe's description (Cat. of Bds. I, p. 359) of B. reinwardtii, but is most certainly different from the New Ireland species, which Dr. Sclater places under the same name. P.Z.S., 1877, p. 109.

The Port Moresby bird has five distinct black bars on the basal portion of the tail, and the apical third of the tail black on the central two feathers, diminishing in extent on the remainder, until on the outermost feathers it forms a sub-terminal band, the black basal bands are margined on both sides with white on the inner webs of the feathers of the upper surface, which are white at the extreme base. All the bars extend right across the feathers on the upper surface, but none do so on the under surface, except in the centre two feathers; the breast, flanks, upper part of the thighs, and centre of abdomen are banded; the primaries and most of the secondaries are banded right across on all, except at the base of the secondaries; in our New Ireland birds the primaries are not crossed altogether, and the bands are confined more to the tips of the feathers, the bands on the base of the tail are different in form, and the apical half of the tail is black.

5.-Milvus affinis, Gould, P.Z.S. 1837., p. 140.

I have only seen two specimens of this hawk from the New 
Guinea Coast, they are of a darker race than those usually met with in Australia.

6.-Henicopernis longicauda, Garnot, Voy. Coq. I, p. 588, pl. 10 (1826); Sharpe, Cat. Birds I, p. 341.

Milvus striatus, Diggles, M.S.S. Ill. Aust. Ornith.

One specimen only from Mr. Broadbent's collection. Loc., Laloki River.

7.--Macherhamphus alcinus, Western.

Sharpe, Cat. Acc. I, p. 342.

A fine pair, male and female, of black hawks belonging to this species were procured on the Laloki River, on October 16, 1877. No information on their habits or nidification was obtained.

There is no sign of a crest of any kind on either specimens, otherwise they resemble $M$. alcinus, (Western) in having the abdomen and flanks brown-with the base of the feathers white. There is however a distinct white collar on the back of the neck, the feathers on the central portion of the collar tipped with black. The feathers of the head, neck, shoulders, and interscapular regions are chiefly black; throat white, with a blackish patch on either side, and a stripe of black down the centre; lower portion of the chest white in the centre, the upper portion mottled with black and white; legs and feet bluish grey, bill black, iris yellow, o total length $17 \cdot 3$ inches, wing $13 \cdot 2$, tail $7 \cdot 3$, tarsi $2 \cdot 1$; middle toe $1 \cdot 7$, its nail $0 \cdot 7$, slightly serrated at the base of the inner margin ; hind toe 0.8 , its nail 1 inch. $q$ total length 17 inches, wing 12.8 , tarsus $2 \cdot 3$, bill from forehead $0 \cdot 8$, from gape 1.5 , culmen 0.9 . The female in this instance, contrary to what I expected, is slightly smaller than the male.

8.-Accipiter cirrhocephalus, Vieill, N. Dict. d' Hist. Nat. X., p. 329 (1817); Sharpe, Cat. B. I. p. 141.

Only one specimen of this hawk was obtained, some distance inland on the Laloki. The rufous tint on the side of the nerk is not continued on the back of the neck; there are other minor differences which can scarcely be specific. The back is of a 
clearer blue grey, and the rufous of the under surface deeper in tint than in the Australian specimens; the bill is larger, the under tail-coverts white and the wings and tail shorter.

9.-Astur sharpei, Ramsay, P.L.S. N.S.W., III, p. 173

Astur cruentus; Sharpe, Jour. Linn. Soc. Zool. XIII, p. 488.

Several specimens obtained, forming a good series of adults and young, in which the characteristic markings of the immature birds of the genus are well exhibited.

This species takes the place of Astur approximans of Australia, and in actions and habits is much the same. It seems to be universally dispersed over the whole of the south-eastern portions of New Guinea.

10.-Astur leucosomus, Sharpe. Cat. B. I, p. 119 (1874).

One specimen only, obtained in Torres Straits-an adult male, in snow white plumage, iris reddish yellow.

\section{PANDIONES.}

11.-Pandion leucocephalus, Gould, P.Z.S. 1837, p. 138 ; Sharpe, Cat. of B. I, p. 451.

One specimen only obtained. This species is however common in the Straits and on the South Coast of New Guinea.

\section{STRIGES.}

Fam. STRIGID

12.-Strix delicatula, Gould., P.Z.S., 1836, p. 140.

This species appears to be not rare about Port Moresby. Specimens were contained in every collection made at this place. The young are mostly covered with white or creamy down, but before they are six months old attain a spotted plumage similar to the adults.

13.-Ninox dimorpha, Salvad. Ann. Mus. Civ. Genov. VI, p. 308.

In Mr. Goldie's first collection there was a species of Ninox, a fledgling, which I previously described in the Pr. L. Soc. of N.S.W., vol. I., p. 338, and respecting which I regret no further information has been obtained; however, I believe this to be the young of Ninox dimorpha, of which we have received a 
specimen from Port Moresby. I may here mention that Ninox odiosa of Sclater, and my Ninox nove-britannice are two very distinct species; both birds have been examined and compared by me before $N$. odiosa was sent to Dr. Sclater. See P.L.S. of N. S.W., I., p. 369. How the editors of the Ibis could come to the conclusion that both these species, ( $N$. odiosa and $N$. novebritannice) were the same, I cannot imagine. I do not suppose they took the trouble to compare the descriptions.

14.-Ninox albomaculata, $s p$. nov.

This species agrees for the most part with Mr. Sharpe's description of $N$. ocellata, Homb. et Jacq. (Cat. Bds. II., p. 170), particularly in the large white spots on the scapulars and wing coverts. All the upper surface is of an earthy brown tint, head uniform without streaks, upper tail-coverts and outer webs of the tail feathers tinged with fawn color, some of the former with concealed spots of white on the outer webs, tail dark earthy brown with six to eight faint ashy bars, the outer feathers on either side faintly notched on the outer webs with white on the fulvous margin; in other respects like N. ocellata as described by Mr. R. B. Sharpe (t.c. p. 170) ; bill dark horn color ; feet brown?

Total length 15.5 in., wing 10.2 in., tail 6.1 in., tarsus 1.5 , bill $1 \cdot 15$, culmen 1.35. The only skin is in such a bad state that it is quite impossible to describe it accurately.

From the Laloki River, without sex, but probably a female.

$$
\text { 15.-Ninox undulata, } s p \text {. nov. }
$$

This species is not unlike N. rufa of Gould, but is altogether smaller. It approaches $N$. humeralis, (Homb. et Jacq.) Sharpe's Cat. of Birds, II, p. 180); but on the whole differs so much that I think it should form the type of a new species, which I propose to describe under the name of $N$. undulata.

Adult Male. All the upper surface dull, dark chocolate-brown transversely barred with narrow lines of light fulvous brown, becoming almost white on the rump, scapularies, and outer webs of some of the greater wing-coverts which are tinged with rufous; feathers at the base of cere, and the lores, white with black shafts; feathers on forehead whitish at the base, but barred 
like those of the head, ear coverts blackish brown; vibrissæ long, black, reaching to the outer margin of the culmen; the coverts of the shoulders and margins of the wings, very dark brown, the bars scarcely visible, the median and greater coverts of a much lighter brown, and the bars almost white on some of the outer webs, primary coverts blackish brown, no bars visible; quills blackish brown with 6 or 7 bars of a lighter tint, the bars paler towards the tips of the secondaries; under coverts fulvous, darkest on the edges and shoulders, all closely barred with dark fulvous brown, tail blackish brown with 8 or 9 brown bands lightest at the base, under surface tinged with ashy, and the bars less defined; all the under surface barred with light rufous brown or fulvous, the interspaces and base of the feathers creamy white, the fulvous bars, bounded on either side with a narrow blackish brown line, usually four bars on each feather. The bars have a more fawn or yellowish fulvous tint, having lost the narrow brown conterminous borders on the abdomen and flanks, where the bases of the feathers are white; legs fulvous sparingly barred with brown; under tail coverts white, fulvous towards the end and there crossed with three or four broken hastate bands of fulvous brown; feet yellow, bristles orange; bill bluish horn colour at the base, white at the tip; eyelid bluish, iris yellow.

Total length 16 to 18 inches, wing 11.5 in., tarsus 1.5 , mid. toe (s.u.) $1 \cdot 7$, its claw $1 \cdot 2$; hind toe 1 in., its claw 1 in., tail $8 \cdot 5$.

In the wings the $3 \mathrm{rd}, 4 \mathrm{th}, 5 \mathrm{th}$, and 6 th quills are nearly equal and longest, the 7 th nearly equal to the $3 \mathrm{rd}$. From Mr. Broadbent's collection.

\section{PICARIÆ.}

(Psittaci).

CACATUID $\AA$.

16.-Cacatua triton, Temm.

I believe I am correct in assigning the small white cockatoo (otherwise like $C$. galerita) to this species.

They were found in large flocks throughout the district. The crest in this species is proportionately larger than in $C$. galerita, 
NASITERNIN ÆE.

17.-Nasiterna pusilla, Ramsay, P.L.S., N.S.W. vol. II, p. 105.

I have considered the birds from Port Moresby distinct from the New Ireland species on account of their smaller size, lighter cheeks and deeper blue on the crown of the head. Mr. Goldie obtained the original specimen on the Laloki River in 1876, and Mr. Morton was fortunate enough to fall in with it near the same place in October, 1877. They traverse the stems and thicker branches of the trees in search of food in small flocks of three to five in number, chattering as they creep along, more like mice than birds, thin, stiff, pointed tail-feathers pressed close against the tree while at rest form a good support. In some of their actions they resemble the Sittellae, and their long toes seem specially adapted for this mode of progression; iris brown, legs and feet lead color, bill dark horn color. Broadbent met with a troup of about twelve or fourteen in number, creeping over a nest of Termites, built on a large branch of a tree in the scrub.

\section{PSITTACID $\AA$.}

\section{8.-Aprosmictus chloropterus, sp. nov.}

Adult male. The head and sides of the neck, throat, and all the under surface deep rich crimson, the under tail coverts blackish blue at the base, the tips crimson, tail black above and below, the outer webs above blue, those of the central feathers tinged with green; nape, and hind neck, and a few adjacent feathers on the sides of the chest, lower part of the back, rump, and upper tail-coverts deep rich blue; wings blackish brown, the outer webs of the feathers washed with dark green, the margins of the shoulders, wing coverts, and interscapular region and scapulars, black with a greenish tinge ; from the angle or point of the shoulders to the ends of the scapulars extends a broad band of bright verditer green tinged with yellow, the outer margins of the shoulders tinged with blue, under wing coverts blackish blue; base of the bill coral red, the tip and all the under mandible black ; feet black ; "iris orange-yellow"

"Note like that of the King-Lory," A. scapulatus, Bechst. ( $K B$.)

Total length 15 in., wings $7 \cdot 7$ in., tail 9 in., tarsus 0.8 , bill from nostril $0 \cdot 9$, culmen $1 \cdot 1$. 
Female (or young male?). The rump and upper tail-coverts, blue, as in the male; the primaries and secondaries blackish brown, the outer webs of these feathers, the wing coverts, head, and remainder of the upper surface green; the throat, and sides of the neck green; chest green, with some of the feathers tipped with crimson, breast and remainder of the under surface rich crimson, as in the male, the bases of the under tail coverts black; tail blackish brown above, the outer webs of the three lateral feathers bluish, those of the central ones at the base greenish, under surface black; under wing-coverts green; bill black, an indication of red at the base of the upper mandible; legs and feet black; iris orange yellow. In size the same as the male.

Broadbent obtained this fine species in the mountain district, near the Goldie River, about forty miles inland from Port Moresby.

In describing this species as new, I mention, with regret, that I have not seen a description of Aprosmictus buruensis, (Salvad. Ann. Mus. Civ. Genev. VIII., p. 371), with all the other known species, however, I have compared it and find it quite distinct.

19.-Cyclopsittacus suavissimus, Sclater., P.L.S. 1876, p. 520. pl. 54 t and $q$ (not quite adult).

Many specimens of this beautiful little parrot were obtained, in various stages of plumage. They do not appear to be rare and were found feeding chiefly on the fruit of the native figs in scrubs on the Laloki River. The adult males have a patch of white on the side of the neck just below the ear coverts, and the breast is of a deep orange yellow. In the adult female this spot is of a deep orange (like the breast in the male,) and the colouring of the breast is lighter, the white mark at the gape is reduced to a narrow line, which is sometimes continued on to the chin and forms a margin round the blue of the cheeks. Spot on inner margin of the scapularies almost white.

20.-Geoffroyus aruensis, G. R. Gr., P.Z.S. 1858, p. 183.

This species appears to be not uncommon, nearly every collection that I have seen from the Port Moresby district contained specimens. It would be interesting to get a really good 
series of the young and adults of this bird. The young of the New Ireland bird, (G. cyaniceps, Puch.) which differs very little from this species, may be distinguished by the inner webs of the tertiaries being white towards the tip, while in $C$. aruerisis they are dark brown throughout, the under wing coverts are of a brighter and clearer blue, and the under side of the tail feathers bright green. After the first year the head becomes a deeper rich brown in the young female. In G. cyaniceps, Pucher, the young female has a wash of green over the cheeks which is not visible in $G$. aruensis, $q$. The base of the skull is wider by $0 \cdot 1$, and the back of the head much more round in the $G$. aruensis than in $G$. cyaniceps.

21.-Eclectus polychlorus, Scop., Del. Flor. \& Faun. Insubr., p. 87, n. 27 (1786).

A good deal has been written on the sexes of this and other species of this genus, and their coloration, but I think the matter has, (with respect to the present species at least) by this time been settled beyond doubt. If not, I may mention that Morton, who examined a number of specimens which had just been removed from the nests by the natives, assures me that the young males assume the green dress, and the young females the red dress from the nest during the first year, and that both young red and young green birds were taken out of the same hollow bough in which they were hatched.

This species is very common about Port Moresby. Like the cockatoo (C. triton), they are kept by the natives to supply feathers for decorative purposes, the unfortunate birds being kept almost naked, the demand being usually greater than the supply.

\section{TRICHOGLOSSID $\nexists$.}

22.-Eos fuscata, Blyth, Journ. As. Soc., Beng. XXVII,

$$
\text { p. } 279 \text { (1858). }
$$

A good series of this variable species was obtained, including fully acult males and females, and young birds of the year. Iris yellow, skin at base of bill below, bright orange; bill in adult yellow; legs brownish-black. 
They were shot in company with other Trichoglossi, feeding on the honey of the Melaleuca and Eucalyptus blossoms.

23.-Lorios hypenochrous, G.R. Gr. List. Psitt. Brit. Mus.

$$
\text { p. } 49 \text { (foot note) } 1859 .
$$

Lorius hypœnochrous, var. Gulielmi, Ramsay, P.L.S., N.S.W. Vol. III, p. 106.

A remarkably fine specimen of this species was shot by $\mathrm{Mr}$. Goldie at Cloudy Bay. This bird, which I believe to be a fully adult male, has the interscapular region black, with the faintest shade of blue; on the neck, the black is separated from that of the head by a narrow line of rich crimson; the abdomen and undertail coverts are almost black. I was at first inclined to consider this a distinct species, but on examining the collection of New Guinea Birds from the voyage of the "Chevert" in the Macleayan Museum, I found there another specimen having the interscapular region black, but not to so great an extent. I think therefore that I am correct in assigning Mr. Goldie's bird to Lorius hypoenochrous of Dr. G. R. Gray - of which it is probably a very old male. The figure in the voyage of the "Curaçoa" does not show any black colouring on the abdomen.

24.-Chalcopsitta chloropterus, śalvad. Ann. Mus. Civ. Genov.

$$
I X, p .15 \text { (1876). }
$$

Of this species, the young vary somewhat from the adults in being of a duller hue, and having the whole of the head of a dusky green; the under wing coverts are green, with the greater series red margined with black, a large patch of yellow near the base of primaries on under side; bill, and legs dusky brown. In some of the adults I notice a crimson patch on the occiput, and all have the whole of the front of the head and a patch of feathers on the sides of the chest of the same color. On examination of the plate and description of Dr. G. R. Gray's C. rubrifrons, I see no reason why $C$. chloropterus should not prove to be the young of that species. I have arrived at this conclusion after a careful examination of a very large series. They frequent the Melaleuca and Eucalyptus trees when in flower, feeding on the honey-like fluid found in the blossoms. 
25.-Trichoglossus massene, Bp., Rev. and Mag. de Zool., 1854, p. 157.

This species seems universally dispersed over the whole of the South East end of New Guinea, New Ireland, New Britain, the Duke of York Islands, Solomon Islands, New Hebrides, and New Caledonia, from all of which places I have received specimens, none of which appear to differ, inter se. In the Port Moresby district they were found feeding in the various Eucalyptus and other flowering trees and shrubs.

\section{6.-Trichoglossus subplacens, Sclater, P.Z.S. 1876, p. 519.}

A female of this species was obtained by Mr. H. Shaw about ten miles inland, near the top of Mount Astrolabe. Mr. Broadbent's collection contains an adult male.

\section{Family CUCULID $\approx$.}

\section{7. -? Lamprococcrx minutilus, Gould.}

This is one of the smaller species allied to L. minutitus and L. russata, both of which it much resembles, the outer webs of the secondaries above are slightly margined with rufous, all the remainder of the upper surface of a rufous bronzy green, all the tail feathers rich rufous, washed with blackish towards the tip, all but the centre two, with a spot of white on the inner web; the outer on either side barred with black, white, and rufous, the black bands being the broadest and the white the narrowest, the next feather on either side has three bars of black only.

The chin, throat, and all the under surface of the body and the under tail coverts are whitish, strongly barred with bronzy green, the under wing coverts barred like the breast, except the outer series at the base of the primaries; the primaries towards the base light rufous, the secondaries white at the base, pale rufous towards the centre of the inner webs. Bill black; feet ashy grey. Total length, 5.5 ; wing, 3.8 ; tail, 2.5 ; tarsus, 0.5 ; bill from forehead, 0.65 ; from gape, 0.75 .

The tail is rather square and even, the outer tail feathers being equal in length to the centre ones. The New Guinea specimens do not materially differ from those from the Rockingham Bay 
district and Cape York, all agreeing better with L. minutilus, Gould, than with any other species.

Another individual which I believe is referable to the young of this species is, above, the same in coloration, showing only a little wider rufous margin on the primaries and secondaries, the rufous on the under surface of the inner webs of the wing quills is of a little deeper tint. Throat and chest ashy grey, the rest of the under surface of the body, under tail coverts, and the under wing coverts (except a brownish spot at the base of the primaries) white; the under tail coverts and flanks have a few scattered broad bars of bronzy green, and some of the under wing coverts and axillares show indications of narrow bars of the same tint; the tail is strongly banded as in the adult, but the rufous bars on the outer feathers are very indistinct.

\section{8.-Lamprococcrx lucidus, $\mathrm{Gm}$.}

Only two specimens of this widely distributed species were obtained, they are slightly smaller than those from New Zealand.

\section{9.-Lamprococcrx meyerii, Salvad.}

Ann. Mus. Civ. Genov. VI, p. 82, (1874).

I believe the bird I have under consideration to be referable to this species; the head has a patch of rich rufous on the forehead, the ear coverts, sides of the head, and all the upper surface of a clear rich bright metallic green, the primaries and secondaries dark-brown at the tips, their central portions to the base on both webs, rich rufous; under wing coverts, chin, throat, and all the under surface, strongly barred with bronzy green and white; under tail-coverts white, barred with bronzy green. Length, 6 in. ; wing, 3.5 ; tail, 2.5 ; tarsus, 0.6 ; bill, 0.7 .

\section{0.-? Cacomantis assimilis, Gray.}

Specimens which I refer to this species resemble Cacomantis castaneiventris of $\mathrm{Mr}$. Gould, but have the throat and head bluish ashy grey, and are smaller. The chest, breast, abdomen, and under tail-coverts of rich castaneous red or rufous, a pale cream or buff-colored oblique band across the under surface of the wings, remainder of the under surface of the wings dark 
brown, underwing-coverts rufous, like the breast; all the upper surface of the body dark glossy brown with metallic reflections, the uppertail-coverts of a slightly bluish tint; under surface of the tail ashy brown; all the feathers tipped with white, more extensively on the outer ones, and least on the central two; on the inner webs of the feathers are tooth-shaped markings of white, or of a buffy tinge. Bill black, legs and feet reddish, claws black.

Total length from tip of bill $7 \cdot 5$ in. ; bill from forehead, 0.75 in., from gape 0.8 in. ; tarsus 0.7 in. ; wing 4.15 ; tail 3.9 .

The young is of a dull blackish brown above, each feather margined and barred with rich rufous, the wing quills margined and strongly toothed with the same, the tail somewhat similarly marked, the tooth shaped markings on the margin extend almost across; on the outer two feathers and the uppertail-coverts are barred across with the same rufous tint. The under surface is dark ashy brown, lighter on the flanks, barred with whitish ashy brown and rufous, the under tail-coverts whitish ashy at the base, light rufous towards the tip, strongly barred with blackish brown, bill blackish, legs and feet reddish.

Total length 6.5 in.; wing 4.1 in.; tail 3.9 in.; tarsus 0.7 in.; bill, from forehead, 0.75 in., from gape, $0.8 \mathrm{in}$.

Hab., Laloki River, \&c.

\section{1.-Cacomantis dimetorum, Gould.}

One specimen obtained, which does not appear different from the Queensland examples of this species.

\section{2.-Eudynamis cyanocephala, Lath.}

This species appears to be plentiful ; it is a migratory species, traversing the countries it inhabits in search of food, remaining to breed in such districts as it may find itself in the proper time of year; it usually selects the deep cup-shaped nest of some of the larger species of Honey-eaters, in which it deposits its egg A broken egg laid by a bird shot by Mr. G. Masters at Gayndah 25 th Nov., 1870, is in length 1.4 in. by 0.9 in. in breadth; the color is white, with dull pale purple brown and light reddish brown spots sprinkled over the larger end, the shell is slightly granular. 
33.--Scythrops NOVE-HOLLANDiÆ, Lath.

Salvad. and D'Alb. op. cit. VII., p. 813; Sharpe t.c.p. 492.

Generally distributed over the whole of the South East Coast.

\section{4.-Centropus spilopterus, Gray.}

This species is always more or less plentiful about Port Moresby. Mr. Goldie obtained several specimens in various stages of plumage during his first expedition. The fully adult males become almost entirely black.

35.-Centropus menbekit, Less.

I noticed a fine adult specimen of this species in Mr. Goldie's Collection collected by Mr. Blunden, and another very interesting specimen obtained by Morton exhibits the change of plumage from the young to the adult.

They were found to be rare in the Port Moresby district; the few obtained being shot on the Laloki River, about 15 miles inland.

\section{Family ALCEDINID $\approx$.}

36.-Alcrone affinis, Gray, P.Z.S., 1860, p. 348.

I should have referred the larger blue-backed Alcyones, from the Laloki River to Alcyone pulchra, were it not for their long and stout bills; the blue patch on the side of the chest is confined to that region, and does not extend on to the flanks; it has, moreover, no lilac tinge whatever.

Total length, $6 \cdot 4$ in. ; wing, $3 \cdot 1$ in. ; tail, $1 \cdot 3$ in. ; tarsus, $0 \cdot 4$ in. ; bill from forehead, 2 in. to $2 \cdot 2$ in. ; from gape, $2 \cdot 2$ in. to $2 \cdot 3$ in. ; depth, $0 \cdot 4$ to $0 \cdot 44$ in.

All the specimens were obtained in the scrubs on the river side. I must admit I do not see the difference between the present sp. and A. lessoni (Cass).

37.-Alcyone pusilla, Temm., Pl. Col. 595, f. 3. (1836).

I believe this species to be the smallest of all known Kingfishers, and although they may be far from rare in any district frequented by them, they are always very difficult to obtain; their flght is swift and arrow-like, dashing past like a flash, just over the surface of the water, in the most dense and secluded 
parts of the creeks which wind through the scrubs; they utter a shrill, clear, piping cry, settle abruptly on a bough, and frequently turning round, almost immediately present their dark blue back instead of their white breast, so that if once lost sight of, they are difficult to detect. They were plentiful on the Laloki River during Morton's stay there, and are found also in Queensland as far south as the Herbert River.

38.-Ceyx solitaria, Temm. Pl. Col. 595. f. 2. (1836).

I have seen but two examples of this elegant species from the Laloki River, where it is evidently rare. Both were obtained in the most dense part of the scrubs near the river, at a distance of about 15 miles from Port Moresby.

\section{9.-Thanyiptera galatea, Gray.}

Tanysiptera microrhynchus, Sharpe, Journ. Linn. Soc. Zool., 1877, p. 313.; T. galatea var. minor, salvadori, t.c.

This fine kingfisher is evidently very plentiful in the scrubs fringing the Laloki; both Morton's and Mr. Goldie's collections contained many fine examples. The centre two tail feathers in some of the specimens, attaining the length of 13 inches. I can find no difference between the Port Moresby specimens and some collected by Dr. Beccari, at "Warbresi" in the North West; except in the greater length of the tail feathers and shortness of the bill. Like Tanysiptera sylvia, this species appears to be solitary in its habits except when breeding; they frequent the thickest parts of the scrubs, and seldom go near the water. Morton notes that on one occasion he saw one fly down to the waters edge as if to drink, but scarcely remaining half a minute, dashed off again into the scrub. They breed in November and December, laying 5 round white eggs in a hole dug in a bank, or in the nest of the white ants, Termites.

\section{0.- Tanysiptera salvadoriana, $s p$. nov.}

This species has been looked upon as T. sylvia (Gould), but upon close examination will be found to be quite distinct. Dr. Salvadori has pointed out the chief differences, from specimens obtained by D'Albertis. 
I have examined several specimens obtained by Broadbent, and find all these distinctions constant. This species which otherwise resembles T. sylvia, may at once be distinguished from it by the much lighter colouring of the under surface, and the very different tint of blue of the wings, head, and tail, which has. a greenish tinge; it is moreover, altogether a smaller bird. The centre tail feathers, when fully grown are very much longer, attaining the length of 10.3 inches, the webs are also broader and do not taper so much as in T. sylvia.

Total length from bill to oil gland, $4 \cdot 2$; two centre tail feathers from oil gland, from 8 in. to 10.3 in. ; wing, 3.5 to 3.6 in.; tarsus, 0.55 ; bill from forehead, 1.25, width at nostril, 0.35 , height, 0.37 .

Morton reports having once met with this species some 50 miles inland from Port Moresby, its note differs from that of $T$. sylvia. The specimens are from Broadbent's collection.

41.-Syma товотово, Less. Voy. Coq. Atlas pl. 31 bis, f. 1 (1826).

The saw-billed kingfisher of New Guinea has been usually identified with the yellow-billed kingfisher from Cape York, ( $S$. flavirostris), and indeed I am by no means certain that this view of the case is not the correct one. Mr. R. B. Sharpe in his very excellent monograph, on the Alcedinidæ, has endeavoured to show that they are distinct, but I do not consider that the slight differences, which certainly do exist between the New Guinea and Australian birds, are sufficient to separate them into distinct species. I have lately examined a large series of both the Australian and New Guinea birds, the latter from the South East Coast. I find in the males of the New Guinea specimens, the under surface of the tail feathers, blackish brown, and the half collar round the back of the neck is divided in the middle, by a patch of white in some; in the females, the crown of the head only is black, as pointed out by Mr. Sharpe, and all have a mixture of white in the middle of the collar.

In habits and actions, Syma torotoro resemble the land and not the water loving sections of the Alcedinida. They are found in the most dense parts of the scrub, and live on insects and 
their larvæ; none were obtained within 12 miles of the coast. I have heard of one instance in which the Australian bird has been found in a belt of Mangroves at Cape York.

42.-Halcyon macleayi, Jard and Selb., Ill. Orn. pl. 101. ठ $(1825 \cdot 1839)$.

Many specimens of this species were obtained, showing that it is one of the most common species in the neighbourhood of Laloki River. They do not frequent the scrubs, but are generally found in the opens and forest country. In habits they are much the same as Halcyon sanctus, breed in holes in hollow boughs, or in tunnels dug in the nests of the Termites, at the end of which they lay 5 pearl-white, glossy, round eggs. This species has an extensive range, and is found as far south in New South Wales as the Clarence River, and as far to the north-west as Port Darwin, where it is common (Spalding).

43.-Halcyon albicilla, Cuv., Dumont, Dict. Sc. Nat. XXIX, p. 273 (1823).

Several specimens of this fine species from Coutance Island.

44.-Halcyon sancrus, Vig. and Horsf. Trans. Linn. Soc. XV, p. 206, (1826).

Common everywhere, both on the coast and inland.

45.-Dacelo Gaudichaudi, Quoy et Gaim. Voy. Uran. Zool. p. 112, pl. 25, (1824).

Equally common with the foregoing.

The collections contained several specimens of both sexes. In habits they resemble the species of Australia, particularly in the upward jerking of their tail after calling. Their note is a hoarse squeaking monosyllable.

\section{6.-DACELO LEACHII, var.}

Dacelo intermedius, Salvad. Ann. Mus. Civ. Gen. IX. p. 21, sp. 99 (1876).

I scarcely think that the slight differences visible between the New Guinea birds and Dacelo leachii of Cape York, merit their being separated into distinct species. The blue-backed Dacelo is 
common in the immediate neighbourhood of Port Moresby, as well as inland, and inhabits the open forest country; breeds in hollow boughs, laying 5 eggs, white, 1.65 in. length by 1.33 in breadth.

\section{7.-Melidora macrorhyncha, Less.}

Melidora goldiei, Ramsay. P.L.S. of N.S.W. I. p. 389, (Dec. 27th 1876).

Melidora collaris, Sharpe. Journ. Linn. Soc. Zool. March 1877, p. 313 ( $q$ ).

Since describing the male of this fine species, I have had an opportunity of examining several other specimens all from the same locality. A female procured by Mr. William Blunden, one of Mr. Goldie's collectors, exhibits slightly different markings to the type of the species described in the Proceedings of the Linnean Society of New South Wales. I do not consider this female quite adult, but it may be thus described. All the upper and under surface similar to the male, having the crown of the head black, each feather tipped with bluish or greenish-ochre; the spots on the back, and wings of a greenish-ochre of a brighter and more greenish tinge than in the male; there are a few ochraceous buff on the ear coverts and sides of the neck and throat; the blue tipped feathers of the back of the head and nape are longer than in the type or than in any of the males. The bill is also broader in some specimens than in others.

Female. Total length, 10.3 ; wing, $4 \cdot 7$; tail, 3.6 ; tarsus, 0.7 ; bill from forehead, $1 \cdot 9$, from gape, $2 \cdot 3$, length of hook, $0 \cdot 23$, width opposite nostril, 0.9 , width across gape, $1 \cdot 1$ inches

This Melidora is only found in the dense scrubs, inhabiting such situations as are chosen by Tanysiptera galatea. It procures most of its food on the ground, digging with its bill among the fallen leaves and debris. No information was obtained on its habits or nidification.

I feel convinced that both Mr. R. B. Sharpe and myself have fallen into error in describing this bird as new; it will undoubtedly prove to be the adult male of Melidora macrorhyncha, 
as the females agree very well with Lesson's figure in the Voyage de la Coquille.*

\section{MEROPID $Æ$.}

48.-Merops ornatus, Lath., Ind. Orn. Suppl. p. 35. (1801).

Universally dispersed over the whole Eastern portion of Australia and South East end of New Guinea. Many specimens were obtained.

Family BUCEROTID $Æ$.

\section{9.-Rhytidoceros plicatus, Penn.}

Buceros ruficollis, Vieil. Nouv. Dict. D'Hist. IV. p. 600. (1816);

Ramsay, P.L.S. of N.S.W., vol. I, p. 393.

This fine horn-bill which is far from being rare in the vicinity of Port Moresby, has caused no slight excitement to inexperienced collectors and recent travellers.

The loud rustling of its wings on taking flight, and the immense masses of undigested portions of food, \&c., thrown up by this bird, has given rise to wide conjectures as to its size and the great expanse of its wings; some affirming that they reached to at least 20 feet. Signor D'Albertis has reduced Mr. Stone's gigantic bird to its proper proportions, but I think he has failed to solve the mystery respecting the large heaps of excrement, supposed to belong to some large animal. These heaps are nothing more than the undigested food turned out of the paunches of the kangaroos when slain by the natives according to their custom after killing an animal. The eggrs of this species I have previously described. (P.L.S. N.S.W., vol. I, p. 393).

\section{Family CORACIID $A$.}

50.-Edrystomus crassirostris, Sclater; P.L.S. 1869, p. 121.

Tolerably plentiful and universally dispersed over the district around Port Moresby; in habits and actions, much the same as E. pacificus. Numbers arrived during the months of December

* Since the above was written, I have been favoured with a copy of Count Salvadori's paper on Papuan Birds, in which I find the same opinion expressed. (See Ann. del Mus. Civ. di Genov. XII, 1878). 
and January, accompanied by their young, which are more uniform in coloration and much duller in plumage; they have the bill black, and no light spot on the wing.

\section{Family PODARGID $\nexists$.}

51.-Podargus papuensis, Quoy et Gaim., Voy. Astrol. I, p. 207, pl. 13. (1830).

I am not at all certain that I am not including two species under this name, some agree with the figures of $P$. papuensis, in Gould's Birds of Australia; others are nearly devoid of the white blotches on the wing, are of a dull colour and minutely vermiculated with ashy gray; others again are heavily blotched and marked with white above and below, and have a white superciliary stripe well defined. I find individuals so variable that for the present I prefer leaving them all under the above name, than making a new species. I found considerable variation also, in the specimens I obtained while at Cardwell in 1873-4, scarcely two being alike. The young birds do not show the spots or markings plainly, being often without blotches.

\section{2.-Podargus marmoratus, Gould.}

I am by no means sure that this species is correctly determined. It has two well defined rows of white spots on the wing coverts, and a subterminal spot of black on all the feathers of the upper and under surface. One specimen only obtained far inland on the Goldie River.

53-Agotheles bennettil, Salvad and D'Alb., Ann. Mus. Civic. Genov., vol. VII, p. 816.

One specimen only from Broadbent's collection, obtained on the Goldie River.

\section{Family CAPRIMUILGID $\AA$.}

54.-Caprimulgus macrourus, Horsf.; Salvad. and D'Alb., Sharpe, op. cit. XIII, p. 493.

One specimen obtained by Mr. Goldie; a young bird without the white blotches on the wing-quills, and two adults from Mr. K. Broadbent. All from the Laloki River. 


\section{CYPSELID无.}

55.-Macropteryx mystacea, Less., Voy. Coq. Zool. Atlas, pl. 22 (1826).

This fine tree swallow was not found plentiful, although it is very generally dispersed over the whole of New Guinea, New Ireland, and the adjacent islands, and as far east as the Solomon Islands, and New Georgia.

Two specimens were obtained by Mr. J. H. Shaw near Port Moresby, and another by Broadbent during a trip to South Cape.

\section{6.-Collocalia spodiopygia, Peale.}

A species of Collocalia was met with by Morton on one occasion; it is probably the same as one of the species met with and obtained by Broadbent during Mr. Stone's Expedition. The specimen shot by Morton had built its nest on the under side of a large dead tree, which had fallen across a creek running into the Laloki River. Specimens obtained by Broadbent are identical with Collocalia spodiopygia. I regret to say Morton's specimen, having fallen into the water, was lost.

\section{PASSERES.}

\section{Order PARADISEIDAE.}

57.-Mandcodia atra, Less. Voy. Coq. Zool. I. pl. 2. p. 638.

This species was found very plentiful in the immediate neighbourhood of Port Moresby, and many were obtained in the scrubs on the Laloki River, distance only 12 miles inland. Their note has not that peculiar trumpet-like cry so remarkable in Manucodia keraudreneri and $M$. Gouldii. They were found usually in small troops.

58.-Mandcodia kerandreneri, Less and Garn. Voy. Coq. pl.

Like the proceeding, this bird was found by no means rare, but always at a distance from the coast; all the specimens obtained were shot in the scrubs on the banks of the Laloki River, at least 12 miles inland. Their cry is remarkable and peculiar, and by those who have heard it, said to resemble the 
squeak of a toy trumpet. This species was usually met with in pairs, frequenting the fruit-bearing trees in the dense scrubs. The trachea is external, and similar to that organ in the Australian M. Gouldii, Gray.

59.-Ptilorhis magnifica, Vieill., N. Dict. d' Hist. Nat. XXVIII, p. 167. pl. G. 39. fig. 3 (1819).

One female obtained during a trip to the South-East, probably at Cloudy Bay, and two adult males and two young males sent by Broadbent, obtained about 30 miles inland from Port Moresby.

60.-Paradisea raggiana, Sclat., P.L.S. 1873, p. 559.

This, certainly one of the most beautiful of its tribe, is the only species of the genus found near Port Moresby; its nearest locality is about 12 miles inland on the banks of the Laloki River. They usually frequent the higher branches of the larger trees, but sometimes also those of smaller growth, in search of berries, their chief food, associating in troops of from 5 to 10 in number, the young birds and females predominating. The adult males, easily found by their loud cry of "Wock," "Wock," repeated some 10 or 12 times in succession, are rendered more conspicuous by their habit of elevating and spreading their plumes immediately after "calling," shaking them out as it were, with a continuous tremulous motion for two or three minutes. It was only after their feeding time in the morning that they were observed thus besporting themselves.

Mr. Goldie obtained a very fine series in all the various stages of plumage, and in addition to those shot by Mr. Morton, I have examined others procured by D'Albertis, Dr. James, and Broadbent. From these various collections, I find that the young males resemble the females for at least the two first years, so closely, that the sexes cannot be determined without discretion. The first change is the darkening of the throat, then the change from the dark chocolate to bright green, the frontal band or bar becomes darker, and finally deep dark green, and the velvety yellow feathers of the head take the place of the dull olive yellow of the young birds. After these changes, the two wire-like centre tail feathers 
appear, and attain their full length before the long flowing plumes on the side and yellow bar on the shouider, are full grown.

I find apparently full-grown males, but without plumes, still having the centre two wire-like tail feathers of great length; this seems to argue in favour of the side plumes being shed every year, but I am inclined to the other view of the case as stated above. The Raggiance from the south-east end of the island, are slightly larger in their dimensions, than those obtained about Port Moresby on the Laloki River. The plumes also are longer, thicker, and richer-this may be on account of the age of the individuals.

The natives of Hall Sound, and in fact all along the coast, do a considerable trade in Paradise plumes, taking the birds with nets at night while roosting. Morton failed to obtain any information respecting their nidification, although from the numbers of young birds and females which are to be found all the year round near Port Moresby, they must breed somewhere in the neighbourhood.

At Orangerie Bay and Amazon Bay, large numbers of plumes were obtained from the natives; over 70 were obtained in two days.

61.-Cicinnurus regius, Linn. Syst. Nat. I, p. 166, n. 2 (1766).

Several fine adult males were obtained by Morton, Blunden, and Broadbent, frequenting the most dense portions of the scrubs on the Laloki River. Like others of its tribe, the king bird indulges in showing off something similar to the preceding; its cry is not so loud, but otherwise resembles that of P. raggiana. At intervals, immediately after calling, the green-tipped side plumes are raised at right angles with the body, or brought forward and vibrated while expanded, the wings slightly raised. The adult males appear to be solitary; on no occasion were two or more found together; like the other species they feed on berries, and seem to be of somewhat of a pugnacious disposition. On the whole, they are difficult to obtain until you become acquainted with their note.

In the living bird the bill is bright light yellow, and the legs and feet deep blue; the latter fade very quickly, and the color is quite gone two days after death. (A. M.) 


\section{Sub-family SCENOPIN 2 .}

62.-Chlamydodera cerviniventris, Gould, P.Z.S. 1850, p. 201.

This appears to be one of the most common birds about Port Moresby, but is confined to the coast, not being met with inland. The bowers were also found, and a fine specimen presented to the Museum by Mr. Goldie, obtained during his first expedition, shows them to be made of fine twigs placed in an upright or slightly slanting position, and gently arched over in the middle; the inside and sides of the bower, and sometimes the tops of the twigs, are ornamented with berries.

The fawn-breasted bower bird is usually found in small troops of six to ten in number, and feeds on fruits and berries.

63.-Ailuremdus stonei, Sharpe, Nature, Aug. 17th, 1876, p. 339.

Of this fine species only a few specimens were obtained; they were found in the dense scrubs, feeding on fruit and berries, about 15 miles inland.

\section{MUSCICAPID丑.}

\section{4.-Peltops blainvillei, Garn., Voy. Coq. pl. 19, fig. 2.}

Several males and females were obtained in the scrubs on the Laloki River ; their actions resemble those of Monarcha more than any other flycatcher. I regret to say Morton's notes contain little information on their habits, and nothing respecting the nidification of this species seems to be known.

65.-Piezorhynchus alecto, Temm., Pl. Col. 430. fig. 1. (ơ.)

M. chalybeocephalus, Garn.; P. nitidus, Gould.

The specimens obtained, males and females, do not in any way differ from those from New Ireland and Duke of York Islands, or from the Queensland examples of Piezorhynchus nitidus, of Gould, Bds. of Australia, fol. Vol. II. pl. 88.

\section{6.-Monarcha carinata, Vig. and Horsf.}

Several individuals from the Laloki River. They do not differ from the N. S. Wales specimens; the sexes are alike in plumage, but the males having slightly more black on the chin, 
67.-Monarcha guttulatus, Garn., Voy. Coq. pl. 16, fig. 2.

Several adults and young from the scrubs on the Laloki. The young have the head uniform in color with the back, the ear coverts and throat dull blackish brown, the wings brown, and a wash of rusty yellow on the chest and sides.

68.-Monarcha ardensis, Salvad., Ann. Mus. Civic. Genov. vol.VI, p. 309 ; Sharpe, Journ. Linn. Soc. Zool. XII, p. 497.

M. melanotus, Sclater, P.Z.S. 1877, p. 100.

I have examined a large series (over twenty specimens), adults male and female, and young, of these birds from Duke of York Islands, Port Moresby, and the Aru Islands, and regret to find so little difference between them. The bills of the Port Moresby birds are decidedly smaller; the black of the back extends to the rump, but not on to the upper tail coverts, and the yellow is of a lighter tint than in those from New Ireland and the Duke of York Islands; and in this respect, as pointed out by Mr. R. B. Sharpe (l.c.), are identical with those from the Aru Islands. The following measurements, taken from specimens lately acquired for Australian Museum collection, will illustrate the relative sizes of individuals from the different localities :-

Monarcha ardensis, Salav. Port Moresby.

Total length $\delta, 5 \cdot 1$ in. $5 \cdot 2 ;$ 우 ${ }^{*} 5$ in

Wing , $2.8,, 2 \cdot 75 ;, 2.64$

Tail $\quad$ " $2 \cdot 6,, 2 \cdot 4 ;, 2 \cdot 3$

Tarsus " $0 . \%, " 0.65 ;, 0.6$

Bill from frhd. $0.65,, \quad 0.65 ;,, 0.6$
Monarcha Chrysomelas, Garn. New Ireland $\&$ Duke of York Ids. o, 5.5 in. 오 5.6 ; juv. 5.5 , 2.8, , , $2 \cdot 6$; , 2.7 , $2.5,, \quad, 2.45 ;, 2.5$ $\begin{array}{lllllll}, & 0.7 & , & , & 0.7 ; & , & 0.7\end{array}$ $, \quad 0.7,, \quad, \quad 0.7 ;, \quad 6.5$

* Not quite adult; back, wings, and tail olive brown.

An adult male from the Aru Islands measures 5.2 ; wing, 2.7 ; tail, $2 \cdot 45$; tarsus, $0 \cdot 7$.

69.-Monarcha melanoptera, G. R. Gray. P.Z.S. 1858, p. 178.

One specimen, agreeing well enough with Dr. Gray's description, except in the size.

o Total length, 5.2 in ; wings, 2.9 in ; tail, 3 in ; tarsus, 0.75 in; bill from forehead, 0.65 in ; from gape, $0 \cdot 7$.

Loc., Goldie River, from Mr. Broadbent's collection.

70.-Arses enado, Less. and Garn., Voy. Coq. pl. 15, fig. 2 ( $q$ ) Arses telescopthalmus, Less. and Garn., Voy. Coq. pl.18, fig. 1 ( $\left.\sigma^{\star}\right)$ 
This species was found tolerably plentiful on the Laloki River. Its range extends over the greater portion of New Guinea, New Ireland, and the Duke of York Islands.

\section{1.-RHIPIDURA SETOSA, Quoy and Gaim.}

Voy. de l'Astrol. I, p. 181, t. 4, f. 4 (1830); R. gularis, Mull.

I see no difference between the Port Moresby specimens and those from New Ireland and Duke of York Islands, which differ but very little from $R$. isura, of Gould, from Queensland.

72.-Rhipidura castaneothorax, sp. nov.

Adult male. Head, and all the upper surface of the body, dark bluish slate color, tail blackish brown, below almost black, above lighter, the outer three feathers largely and the fourth on either side slightly tipped with white; wings blackish brown above, lighter below, the margins of the inner webs on the inner side tinged with light brown, the margins of the shoulders, the outer row of the smaller wing coverts, and the coverts of the secondaries like the back, and tipped with a white spot, tinged subterminally with pale rufous; a white line extends from above the lores over the eye in a broken line to above the ear-coverts; chin, and a line on either side of the throat to below the ear-coverts, white; a narrow band between the chin and chest black; chest, breast, underwing-coverts, and remainder of the under surface rich cinnamon rufous, paler on the abdomen : under tail coverts white, tinged at the base with light cinnamon. Bill dark horn color, legs reddish brown, bristles black, extending to beyond the bill.

Total length, $5 \cdot 3$ in. ; wing, 3 in ; tail, $3 \cdot 2$; tarsus, $0 \cdot 6$; bill from forehead, 0.5 .

This pretty species, which comes near to R. hyperythra (Gray), and $R$. vufiventris of Muller, was obtained by Mr. Kendal Broadbent on the Goldie River, about 40 miles inland.

\section{3.-Rhipidura ambusta, sp. nov.}

Head brown, becoming reddish brown on the hind neck, interscapular region and wing coverts; becoming deeper, and darker in tint on the back, rump, and upper tail coverts, where it 
is almost rufous; wings rich brown, the outer webs of the quills above with a rufous shade; tail above and below, and the under tail-coverts, black ; the basal portion of the feathers on the forehead and a line over the eyes, lower portion of the ear-coverts, and the throat white; chest blackish, becoming brown on the breast, each feather with a white shaft, and a triangular spot of white at its tip, the remainder of the under surface brown; under wing coverts mottled brown and white. Bill and bristles black, lower mandible white, its tip brown, legs black.

Total length, $6 \cdot 4$ in.; wing $2 \cdot 3$; tail, $3 \cdot 6$; tarsus $1 \cdot 2$; bill from forehead, 0.7 in, from gape $0.8 \mathrm{in}$.

The wings of this species are very broad and comparatively short, the 4th, 5th, 6th, and 7th quills nearly equal and longest, the 8 th equal to the $3 \mathrm{rd}$. All the body feathers are more or less decomposed.

74.-Sauloprocta tricolor, Vieill.; Salvad et D'Alb. Ann. Mus. Civ. Gen. VII., p. 23.

Muscicapa melaleuca, Quoy et Gaim, Voy. de l'Astrol. I. p. 180. t. $4, f .3$.

On comparing the Port Moresby specimens with some from New Ireland I can find no difference between them, they are undoubtedly identical with Muscicapa melaleuca of Quoy and Gaimard.

In some of the adult males I find white dots on the throat and chin feathers, they differ but little, if anything, except in size, from the New South Wales S. motacilloides.

75.-Micreca flavigaster, Gould, Bds. Aust., fol. vol. II., pl. 94.

Common in the neighbourhood of Port Moresby and on the Laloki River. From Morton's notes I gather that this species has considerable power of song, being heard at daylight in the morning pouring forth its melodious warbling notes. When I met with this same species on the Herbert River, in Queensland, during the months of March and April, its singing had ceased, this was just after the moulting season. Its nest and eggs are scarcely to be distinguished from $M$. fascinans of New South Wales. 
The Port Moresby birds have the crown of the head darker, and a more olive brown tinge on the upper surface, than is seeu in the Queensland specimen of this species.

76.-? Micreca flatovirescens, G. B. Gray, Salvad and D'Alb. Ann. Mus. Civic, Genov. VII., p. 21.

Adult male, All the upper surface and the sides of the neck dull olive green, wings and tail dark brown, the outer webs of the feathers margined with the same tint as the back, the inner webs of the under surface inclining. to white, under wing-coverts yellow, a very narrow line of yellow feathers on the eyelid, sides of the head and ear-coverts tinged with olive yellow, all the under surface olive yellow, becoming clearer yellow on the throat, chest, abdomen, and under tail-coverts.

Bill black above, lower mandible yellow, legs and feet yellow.

Total length 4.8 in., wing $3 \cdot 1$ in., tail $2 \cdot 5$ in., tarsi $0.55-0.56$, bill from forehead $0 \cdot 65$, from gape $0 \cdot 75$, from nostril to tip 0.45 ; breadth at nostril 0.2 ; at gape 0.35 .

This species is very close to Microeca flavovirescens but may hereafter prove distinct; the lores are not white, although the basal portion of the feathers incline to that color there is no yellow ring round the eye, and the total length is smaller by half an inch.

Broadbent states that he shot this bird in the scrubs, and that it had the habits and actions of an Eopsaltria.

Loc. Mountain scrubs, Goldie River.

77.-Eopsaltria placens, $s p$. nov.

Adult male. All the head, nape, ear coverts, and chin dark slatey brown; the back of the neck, back, upper wing coverts, and all the upper surface greenish olive; wings and tail very dark brown, the outer margin of the wing quills and of the tail feathers washed with the same greenish olive tint above, lighter below; a dark olive spot at the base of the primaries, preceded by a spot of white; the inner margins of the quills whitish towards the base; the margins of the wings below and the under wing coverts bright yellow; the lower part of the throat and upper portion of 
the chest, and extending on the sides of the neck to the ear coverts, the lower portion of the breast, and the abdomen, flanks, and under tail coverts bright rich yellow; a band across the breast greenish-olive like the back, the olive extending slightly towards the flanks over the axillaries; bill black; "iris brown; legs and feet bright orange." (K.B.)

Total length, 5 in to $5 \cdot 2$; wing, 3.55 ; tail, 2.25 ; tarsus, 0.85 ; hind toe, 0.5 ; bill from forehead, 0.77 ; from gape, 0.85 ; from nostril to the tip, 0.45 ; bristle black, extending to nearly the tip of the bill; bill robust.

The female is the same in plumage, but slightly smaller, 4.8 ; wing, 3.35 ; tail, 2.15 ; tarsus, 0.75 ; hind toe, 0.4 in. ; bill from forehead, 0.72 in.; from gape, 0.8 ; from nostril to tip, 0.4 . in.

Loc., Mountain scrubs, near Goldie's River.

This is a fine robust species, with a strong bill, and wings reaching to the end of the tail. It exhibits much of the form and general appearance of the genus Leucophantes of Dr. Sclater.

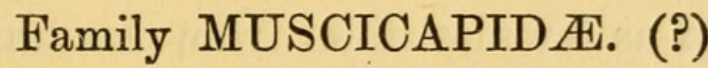

78.-Gerygone inconspicua, Ramsay, P.L.S., N.S.W., vol. III, p. 116.

This species comes near $G$. chloronotus of Mr. Gould, but differs in having a pure white throat; and the chest, breast, abdomen, and under tail-coverts citron yellow; from $G$. albogularis, it may be distinguished by having the tail of a uniform tint, without any bar or white tip; a spot in front of the lores, and a ring round the eye, white; an oblique blackish spot, from in front to under the eye, across the gape; flanks tinged with olive; under wing coverts white, washed with citron colour; tail and wings brown above, the outer webs washed olive; the quills lighter brown below, shafts of the tail feathers white at the base below, brown above; all the upper surface of the body olive brown, tinged with green; bill black; legs and feet lead colour.

Total length from tip of bill, $3 \cdot 7$; wing, $2 \cdot 1$; tail, $1 \cdot 7$; tarsus, $0 \cdot 7$; bill from forehead, 0.5 . Sex $\delta$ ?

Hab., scrubs on banks of Laloki River, where Morton informs me he obtained it among the leafy tops of the trees. 
79.-Gerygone cinerascens, Sharpe, Journ. Linn. Soc. Zool. XIII, pp. 494, 495.

Two specimens, closely allied to G. albogularis, Gould. A young bird, which I believe to belong to this species, has a tinge of olive brown on the upper surface, rump and upper tail coverts light brown, throat light yellow. Morton and Blunden obtained this species on the Laloki River during the months of July and August.

\section{MALURID $A$.}

80.-Malurus alboscapulatus, Meyer, Sitzber. der. k. Ak. der Wissensch. zu. Wien. LXIX, p. 496 (1874).

This well-marked species is universally dispersed over the whole of the south-east coast. It is plentiful on the grassy slopes about Port Moresby during the months of April, May, and June, and are usually met with in small troops of five or six in number. In habits and actions they closely resemble the Australian species of the genus. On examining a large series I find those marked as females differ from the males in having the wing quills brown instead of black; but I think this is rather a sign of immaturity than a sexual difference, as the young are chiefly of a dull brown colour.

81.-? Todopsis cyanocephala, Quoy. et Gaim. Voy. Astrol. t. $5, f .4$. Todopsis bonapartei, G. R. Gray, P.Z.S. 1858, p. 177 (female). T. cyanocephala (Q. et G.); Ramsay P.L.S.N.S.W. III. p. 108.

This beautiful species is found all along the south-east coast. It is not common in the Port Moresby district; the few obtained were all shot on the Laloki River, and were found frequenting the thickest parts of the scrubs, always in pairs, hopping over the ground, and searching among the fallen leaves and low vines for insects, carrying the tail erect after the manner of the Maluri, from which they differ in habits chiefly in confining themselves to the scrubby parts of the country, being seldom if ever seen in the opens. After a careful examination of the plates and descriptions of T' cyanocephalus of Quoy and Gaimard, and T. bona partei of G. R. Gray I feel convinced that the latter is merely the female of the 
former. The tint and intensity of colouring varies a little in the males, but both the male and female from Aru Islands agree exactly with the Port Moresby specimens.

\section{2.-Cisticola ruficeps, Gould. \\ Gould, Bds., Aust., fol. vol. III, pl. 45.}

Specimens of this Cisticola were obtained at Port Moresby, where they were tolerably plentiful on the grassy slopes during the months from March to June. I can find no material difference between them and those from New South Wales. The young and females have blackish striæ on the head, and the tails longer than in the adult males.

83.-Cisticola lineocapilla, Gould.

Gould, P.Z.S., pt.XV, p. 1 ; Bds. Aust., fol., vol. III., pl. 43.

A specimen, which I refer to this species, was obtained, I believe, during a trip to South Cape, probably at Bramble Haven.

\section{Family HIRUNDINID Æ.}

84.-Hrdrochelidon nigricans. Less.

Hirundo nigricans, Less. Compl. Buff., t. VIII, p. 497.

This swallow was obtained about 15 miles inland; they were not found plentiful; one specimen only in Mr. Goldie's collection obtained by $\mathrm{Mr}$. Wm. Blunden.

85.-Hirundo Javanica, Sparrm. Salvad. t. c. p. 23 ; Ramsay, op. cit. $I, p .388$.

One specimen obtained. It seems distributed over the whole of the south-eastern portion of New Guinea and Torres Straits.

DICRURID $Æ$.

86.-Dicrurus carbonarius, $B p$.

Chibia carbonaria, Mull. ; Sharpe Journ. Linn. Soc., Zool. XIII, p. 499.

Common everywhere in the Port Moresby district, and all along the south coast. 
One specimen, which does not differ materially in other respects, has a very short thick bill, swollen laterally, curved and ridged; this may be an individual peculiarity, as I have not found others at all resembling it in this respect.

The bill from forehead, 1.3 ; from nostril to tip, 0.8 ; culmen, 1.5 ; width at nostril, 0.5 ; height, 0.5 ; width at base, 0.7 ; height at base, 0.55 .

ARTAMIDA.

87.-Artamus leucopygialis, Gould; Ramsay, P.L.S., N.S.W., vol. I, p. 392 ; Sharpe, t.c. p. 501 ; Ramsay, List. of Aust. $B d s ., s p .75$.

This species seems to be very generally distributed over Torres Straits and the south coast of New Guinea. I have seen specimens in every collection that I have examined from those parts. The birds were common about Port Moresby itself, and also for twenty miles inland, and at Cloudy Bay. It has also been found over the whole of the southern, eastern, and northern portions of Australia.

\section{DICAID A.}

88.--Dic在u rubrocononatum, Sharpe; Nature, 17th Aug., 1876, p. 339, id. Journ. Linn. Soc. Zool., XIII, p. 496.

This beautiful little species was first obtained during $\mathrm{Mr}$. Macleay's expedition to New Guinea. Messrs. Broadbent and Petterd also obtained fine specimens during Mr. Stone's expedition, from which Mr. R. B. Sharpe took his descriptions.

Morton found them frequenting the topmost branches of some low trees in the watercourses on the hill sides near Port Moresby, feeding on berries.

\section{9.-Melanocharis, $s p$.}

Probably M. unicolor of Salvadori; Ann. Mus. Civ. St. Nat. Genov. XII, p. 333.

The whole of the plumage black, with a greenish metallic gloss ; except on the quills ; underwing coverts and axillaries snow white; lateral feathers of the under tail coverts blotched at the base with white and an indication of a spot of white at the tip of the inner web of the outer tail feathers. 
Should this species prove to be distinct from $M$. unicolor, I propose for it the name of $M$. bicolor.

Total length, $4 \cdot 2$ in.; wing, 2.55 in.; tail, 2 in. ; tarsus, 0.7 in. ; bill from forehead, 0.55 in ; from gape, 0.6 in ; from nostril to tip, 0.3 in.

One specimen only obtained by Kendal Broadbent, who informs me he found it feeding on the berries of a species of Ficus, on the Goldie River.

\section{PITTID丑.}

\section{0.-Pitta nover-guinee, Mull. and Schl.}

During certain seasons this Pitta appears to be tolerably plentiful, and specimens have been obtained by nearly every collector visiting New Guinea. They are distributed over the whole of the south-east coast and on the adjacent islands. All the specimens obtained near Port Moresby were from small patches of scrub and jungle in the ravines and water-courses on the hill sides. During the great drought of 1877-8 no Pittce were to be found in the district, but during March and April, 1878, they returned in considerable numbers.

\section{1.-Pitta macklo'tis, Temm.}

One specimen, an adult male in fine plumage, iris dark-brown, bill black, in Mr. Broadbent's collection.

\section{EUPETID $\AA$.}

92.-Eupetes nigricrissus, Salvadori; Ann. Mus. Civ. St. Nat. Genov. IX, p. 36 (1876).

Mr. Goldie and Broadbent obtained this species on the Goldie River, about forty miles inland from Port Moresby. In the female there is an indistinct line of whitish over the black lores and over the black behind the eye and ear coverts; the whole of the primaries, except the outer edges of the inner feathers, and the under surface of the tail feathers, with the under tail coverts, are black; in other respects like the figures of E. corrulea in Gould's Bds. of New Guinea-iris red; bill, legs, and feet black. 
Broadbent informs me this species frequents the thick parts of the scrubs, and its actions are not unlike those of the Psophodes crepitans; its voice is loud and clear.

Three specimens from Mr. Broadbent's collection.

Loc., mountain scrubs, Goldie River.

\section{CORVIDA.}

93.-Corvus orru, S. Mull.; Ramsay, P.L.S., N.S.W., vol. I, p. 392 ; Sharpe, op. cit., p. 501.

On comparing the black crows obtained on the Laloki and about Port Moresby, with those obtained by the Rev. George Brown at New Ireland and Duke of York Islands, I find no material difference between them, and, notwithstanding the valued opinion of so high an authority as my friend, Mr. R. B. Sharpe (P.Z.S., 1877, p. 105, note 1), I believe both will prove to be identical with Corvus orru.

94.-Gymnocorax senex, Less; Sharpe, Cat. B. III., p. 50, id. Journ. Linn. Soc., Zool., XIII, p. 501 ; Ramsay, P.L.S., N.S.W., vol. I, p. 392.

Specimens of this species were obtained in the open forest land about the Laloki. These birds were not so plentiful as at the time of Mr. Goldie's first expedition to Port Moresby; perhaps the extreme drought, which was the means of causing many species to visit the coast, was instrumental in driving this species away. They were also found a considerable distance inland.

"Bill horn blue, iris white, skin round the eye bright orangeyellow, legs blackish-brown." (K.B.)

\section{ORIOLID A.}

95.-Oriolus striatus, Quoy and Gaim.; Ramsay, op. cit. I, p. 391 ; Sharpe, op. cit. XIII, pp. 82, 319, 500, et Cat. B. III, p. 210.

Tolerably plentiful all along the South Coast; in habits and actions it closely resembles the Australian members of the genus, 
96.-Sphecotheres SalvadoriI, sharpe; Cat. B. III, p. 224, pl. XII; id Journ. Linn. Soc. Zool. XIII, p. 500; S. flaviventris, Ramsay, op. cit., vol. I, p. 391.

This species is very numerous, and, in fact, may be looked upon as one of the most common birds in the district. They are usually found in the fig trees, the fruit of which they seem particularly fond. The young males resemble the female in plumage.

S. flaviventris must be omitted from the list of Port Moresby birds, having been recorded by me in error from that locality.

STURNIDAA.

97.-Eulabes dumontir, Less; Sharpe, Journ. L. Soc. Zool., vol. XIII, p. 318 ; id.p. 501 ; Ramsay, P.L.S., N.S.W., vol. I, p. 392.

A bundant everywhere along the coast and also inland.

98.-Eulabes orientalis.

Mino robertsoni, D'Albertis; Ibis. 1877, p. 368.

Not plentiful. Morton and Goldie obtained it on the Laloki River, and Broadbent some thirty miles inland. The young have the head, throat, back, and wings black; above the chest, yellow mottled with black; and the breast and abdomen greenish black, with the tips of the feathers yellow; legs and bill yellow.

Total length, 8.5 to 9 in.; wing, 5.3 in.; tail, 2.8 ; tarsus, 1.35 ; bill from forehead, 1 in.; from the nostril, 0.65 ; from gape, $1 \cdot 2$ in. (jwv.).

99.-CaLoRnis CANTOROIdes, Less. Sharpe, t. c., p. 318 ; id.p. 501.

C. cantor, Ramsay, op. cit. I, p. 38.

Plentiful in all the districts surrounding Port Moresby, and also obtained inland as far as the Goldie River.

100.-Calornis metallica, Temm.

Calornis viridescens, Gray. Sharpe, t.c., pp. 318, 501.

I. can see no difference between the long-tailed glossy starlings from Duke of York Island, Cape York, Trinity Bay, and Port Moresby; they are probably all one and the same species as described by Temmink under the name of $C$. metallica. 


\section{CRATEROPODID压.}

101.-Pomatostomus isidori, Less.

These birds were met with in small flocks of from five to ten in number; they were particularly active and restless in their movements, flying from tree to tree, hopping about the branches, and chasing each other from limb to limb. When feeding, they usually resort to the ground under the trees, their food being insects and their larvæ. I have received no information on their nidification; but in this they will doubtless be found to resemble the Australian members of the genus, all of which build a somewhat bulky flask-shaped nest of sticks, and lays five to eight eggs of a sienna-grey or brown, with darker hair-lines and marblings over the whole surface.

The eggs of all the Australian species have the peculiarity of being easily washed white; the coloring matter, which appears to be confined to the surface of the shell, is readily removed with

little water by gently rubbing. This peculiarity I have also observed in the eggs of the Bronze Cuckoos (Lamprococcyx).

\section{I,ANIID丑.}

\section{2.-Rectes ferruginea, $B p$.}

These birds traverse the scrubs among the larger branches of the trees, in flocks of ten to fifteen in number, searching for insects, which are their principal food. They were by no means rare, and frequently accompanied by a pair or more of the black fork-tailed fly-catcher, Dicrurus carbonarius.

103.-Colldricincla Brdnnea, Gould, P.Z.S., pt. VIII, p. 164 ; id. Handbook Bds. Aust. I, p. 223; Sharpe t. c. p. 499.

This is apparently a very common bird in the neighbourhood of Port Moresby and further inland. The New Guinea birds of this species are of a lighter and more ashy tint than those I have received from North Australia.

\section{4.-COLLURICINCLA MEGARHYNCHA.}

Musicapa megarhyncha, Quoy and Gaim., voy. de l'Astrolabe, pl. 3, fig. 1. Ois. p. 172.

This species was obtained in the dense scrubs on the Laloki 
River. In its habits and actions it resembles the N. S. Wales Colluricincla rufigaster, Gould, to which species it is most closely allied, if not identical. C. parvissima, Gould, of which I have examined numerous specimens, appears to me to be quite a distinct species.

105.-Cracticus cassicus, Bodd; Sharpe, t.c. p. 499 ; id.p. 317.

This species is numerous about Port Moresby and on the Laloki River, and frequents the open country, usually being found in flocks of five to ten in number during the winter months.

106-Cracticus mentalis, Salvad. and D'Alb. Ann. del. Mus. Civ. di St. Nat. Genov. VII, p. 824 (1875); Sharpe, t.c. p. 317 and 499 ; Ramsay, op. cit. I, p. 392.

This is a smaller species than the preceding, and not so plentiful. Mr. Goldie obtained it on the Laloki River during his first expedition, and towards the south-east in February last. The young have the head marked with sagittate spots of brown, and nearly the whole of the upper surface of the same tint.

107.-Cracticus quoyi, Less.; Voy. Coq. pl. 14; Ramsay, op. cit. p. 392 ; Sharpe, t.c. p. 499.

This species was found to be rare in the Port Moresby district, two only being obtained on the Laloki River; they do not differ in any way from the Queensland specimens.

\section{PACHYCEPALIN $Æ$.}

\section{8.-Pachycephala melanura, Gould.}

Tolerably common on Coutance Island; none were obtained near Port Moresby.

109.-PAChycephala collaris, Ramsay, P.L.S. of N.S.W., vol.

$$
\text { III, p. } 74 .
$$

This fine species, which comes nearest to Dr. Gray's Pachycephala chlorura, was obtained on Teste Island. The female, however, is quite different from the sex of that species; the male has no trace of black in the tail, which is quite uniform in colour, even to the very tips; the bill is comparatively larger and 
stronger than in any other species I have met with. Total length, 6 in. ; wing, 3.5 ; tail, 2.6 ; bill, 0.9 ; from gape. 1 in. $q$ Total length, 6 in.; wing, 3.7 ; tail, 2.7 ; bill, 0.9 ; from gape, 1 in. $\delta$

\section{0.-Pachyce phala, $s p$.}

One specimen, a male, closely allied to T. collaris and melanura, but having an ashy-grey tail, and the forehead and earcoverts jet black, the crown blackish, becoming slaty-black on the occiput; the yellow collar is intercepted on the head and neck; bill strong; black throat-band narrow.

Loc. Teste Island.

111.-Pachycephala fuliginata, Ramsay, P.L.S. of N.S.W., vol. III, $p .74$.

This was the only species of Pachycephala obtained near Port Moresby; it comes from the Laloki River, where it was not common. The female, obtained by Broadbent, has all the upper surface greyish ashy-brown, with faintly darker striæ down the centre of the feathers on the head, inter-scapular region, and upper tail-coverts; wings and tail dark brown, lighter below; the primaries very narrowly, and the secondaries and coverts margined with ashy; throat white, with short brown shaft-lines; the chest shaded with light ashy-brown, forming an indistinct cross-band, and, like the throat, the feathers are ceutered with brown shaft-lines; breast creamy white; abdomen, flanks, and under tail-coverts white; under wing-coverts and axillaries creamy-white; inner margin of the primaries and secondaries below whitish. Total length, $5 \cdot 2$; wings, $3 \cdot 15$; tail, $2 \cdot 4$; tarsus. 0.7 ; bill, 0.6 .

\section{2.-Pachycephala brunnea.}

Eopsaltria brunnea, Ramsay, P.L.S. of N.S.W., vol. I, p. 391.

All the specimens of this species obtained were shot in the scrubs on the banks of the Laloki River. I have received no information on its habits, which I much regret, as I have grave doubts as to its genus; the large bill would place it with the Pachycephalino, although the wings do not altogether agree with those of the numbers of that genus. 


\section{CAMPEPHAGID Æ.}

113.-Graucalus strenda, Schleg., Ned. Tïdschr., Dierk. IV, p. 44 (1871).

Mr. Goldie's collection contains some fine examples of this species, they were obtained some 15 miles inland from Port Moresby. I believe this is the largest billed Graucalus known.

114.-Graucalus melanops, Lath; Gould, Bds. Aust., fol., vol., $p l$.

I have seen several specimens of this species from Port Moresby, none of which appear to me to differ from those of the same species found in Northern Queensland.

115.-Gradcalus angustifrons, Sharpe, Journ. Linn. Soc. Zool. vol. XIII, No. 66, p. 81 (1876).

Although somewhat similar to $G$. hypoleucos, this species is quite distinct, and may at once be distinguished by the paleness of the color on the head and the deep black frontal band, the feathers of the lores and at the base of the upper mandible on the forehead are slightly raised above adjacent feathers.

116.-Edoliisoma melas, S. Mull.

Lanius melas, Less. and Garn.; Less. Man. d'Orn. I, p. 128 (1828) Campephaga marescotii; Homb. et Jacq., Voy. au Pole, Sud, pl. $X$, fig. 2.

This species is comparatively rare, two obtained were shot on the Laloki River.

\section{7.-Graucalus (Edolisoma) plumbea, Mull.}

Broadbent's collection contains an adult male of a species of Graucalus which I think must be referred to this species. It is closely allied to $G$. jardinii, a little smaller, and has a short robust bill. The lores are black, the whole of the upper and under surface plumbeous, the wings black margined outwardly, with plumbeous narrowly on the primaries, which have a line of white on the margin of the inner web; all the tail feathers except the two centre ones black; the central ones, except at the tip, and the bases of the three next on either side, washed with 
plumbeous; all the under surface plumbens, the axillaries and under wing coverts, and the ends of a few feathers on the centre of the abdomen barred transversely with narrow white lines, the under surface of the quills ashy blue. Total length, 8.8; wing, 5.5 ; tail, 4.2 ; tarsus, 0.85 ; bill from forehead, 0.85 ; from nostril to tip, 0.55 ; from gape, 1 in.

Loc. Mountain scrubs, Goldie River. I regret I have no description of $E$. plumbea, Mull, to refer to.

\section{8.-Edolisoma, $s p$.}

This species comes very close to L. schisticeps (Homb. et Jacq.) I can find no description of it in any works at my disposal, but as the bird is common in the Port Moresby district and all along the South-East Coast, it is probably an old described species. I give a short description of the bird here, by which it may easily be recognised :-

Adult Male. All the upper surface dark cinnamon, wings dark brown, the outer webs margined with cinnamon, the head of a darker and more brownish tint, lores blackish, sides of the head, throat, chest, and all the under surface rich bright crimson, paler on the under wing coverts, and towards the base on the inner webs of the quills.

Total length, 8.6 ; wing, 4.7 ; tail, 4 in ; tarsus, 0.9 ; bill from forehead, 0.9 .

There are several specimens in the collection, both males and females, the latter differ but little from the former. I was inclined to consider this bird the female of E. melas, but only two of this latter species were obtained while the former were by no means rare.

119.-Campephaga boyeri, Q. et Gaim., voy. au Pôle, Sud., Ois. IX, fig. 3.

I have seen specimens of this species in several collections made along the South East Coast, and at Port Moresby, Hall Sound, Katow, \&c. The male has the black from the lores, extending under the throat; all the females I have examined have not any black on the throat, 


\section{0.-Campephaga sloetir, Schleg.}

One specimen, an adult male, of this beautiful species sent by Broadbent, has the black of the throat extending well over the chest, and the yellow of the sides of the nape extends to the crown of the head.

Loc. Goldie River.

121.-Lalage rufiventris; Homb. et Jacq., Voy. au Pôle, Sud., pl. $X I$, fig. 1.

In all the specimens of this Lalage I have seen from Port Moresby, the flanks, abdomen, and under tail-coverts have been strongly tinged with rusty rufous; the transverse bars on the under surface are narrow and close together; the bills vary in size, in some 0.05 longer than in others.

MELIPHAGID $A$.

122.-Mrzomela obscura, Gould. Bds. Aust., fol. Vol. IV, pl. 67. 123.-Conopophila albogularis, Gould. Bds. Aust, fol. Vol. pl. 51.

Both species are found abundant in the Port Moresby district, on the banks of the Laloki ; the young of the latter species resemble the adult, have the under surface white, with a dull brownish band across the chest.

124.-Stigmatops alboauricularis, Ramsay. P.L.S. of N.S.W., vol. III., $p .75$.

Mr. Kendal Broadbent obtained this very distinct species during a trip to the south-east end of the peninsula. It was found frequenting the mangroves and trees near the sea shore on a small island off "Hater" Island. It is easily distinguished from the two Australian species by the extent of the minute silvery feathers behind the eye and near the gape.

125.-Ptilotis germana, Ramsay. P.L.S. of N.S.W., vol. III., pt. $1, p .2$.

I have only seen three specimens of this species from Port Moresby, but I believe it is also found on the islands in Torres Straits. They were obtained on the Laloki River at a considerable distance inland. 


\section{6.-Pfilotis analoga, Rich.}

Ptilotis similis, Jaeq. et Pucher, Voy. au Pôle. Sud. Ois. p. 89.

Ptilotis notata, Gould; Ptilotis gracilis, Gould.

This species seems to be very numerous on the south coast of New Guinea, and also on the islands of Torres Straits. Specimens from Australia, obtained as far south as Rockingham Bay and the Herbert River, do not differ materially in coloration from the New Guinea specimens. Among themselves they differ considerably in size and in the extent of the back feathers, which in some form a large tuft of fluffy feathers extending over half of the upper tail-coverts; in one of the Port Moresby examples, these feathers have stiff shafts, reach to the tips of the secondaries, and are 1.4 inches in length. In this specimen, the narrow line of yellow from the angle of the mouth is continued below the eye and joins the ear-coverts Immediately behind the eye, and on the lores, and in a narrow line below the gape, the coloring is of a darker brown, the bill is straighter and not so large in proportion to the size of the bird, as is usual with Ptilotis similis, or P. notata, of Gould, which I believe is identical with the present species.

Total length of a Port Moresby specimen, 6.5 ; wing, 3.2 ; tail, 3 ; tarsus, $0 \cdot 9$; bill from forehead, $0 \cdot 7$; from gape, $0 \cdot 7$.

127.-Ptilotis versicolor, Gould. Bds. Aust. Handbook, I., p. 506 ; Ramsay, P.L.S., N.S.W., III., p. 111.

One specimen only from the Laloki River.

128.-Xanthotis filigera, Gould.

The bird I have, with some doubt, assigned to this species, differs from $X$. filigera, of Gould, in having no whitish lines on the nape, and the yellow line through the ear-coverts is of a much deeper tint.

129.-Gliciphila subfasciata, Ramsay, P.Z.S., 1868, p. 385 ; Gould, Bds. New Guin., fol. vol. I, pl.

Morten obtained specimens of this species from the Laloki River scrubs; they differ slightly from the type specimens figured by Mr. Gould, and may hereafter prove identical with $G$. 
modesta of Dr. G. R. Gray; it has, however, no markings on the flanks, and the indistinct curved markings are confined to the sides of the chest and breast.

130.-Tropidorhtnchus NOVe-GUinee, S. Mull.

This is one of the most common birds about Port Moresby, traversing the district in flocks of from ten to twenty in number; feeding in the fruit trees and frequenting also those in flower, particularly the Erythrina, or "coral" trees. Like the New South Wales T. corniculatus, they proved themselves a noisy and pugnacious species.

131.-Melithreptus albogularis, Gould. Handbook Bds. Aust. I. p., 571 ; Ramsay, List Aust. Bds., sp. 394.

This widely-distributed species appears to be plentiful among the scrubs on the Laloki River; it frequents various flowering trees and shrubs. There is not the slightest difference in plumage between the Port Moresby specimens and those I obtained in Queensland. This species was very common to the south-east towards Teste Island.

\section{CINNYRID $Æ$.}

132.-Cinnyris frenatus, S. Mull., Verrhandl. p. 173 (1843); Shelley, Mon. Cinnyr. pt. III. pl.

Judging from the number of specimens obtained, this species must be very plentiful on the south coast and at Port Moresby ; most of those obtained were collected on the banks of the Laloki River. The nest is an oblong purse-like structure, with an opening on the side, the entrance being concealed by a hood. It is suspended from the top to the end of some drooping leafy bough or vine, and composed of skeletons of leaves, mosses, spider's webs, \&c., all matted and closely interwoven. The eggs are three in number, whitish or pinkish white, with reddish spots and dots, some sparingly, others thickly blotched. The young resemble the females. I have also received specimens of this species from Duke of York Islands, collected by the Rev. George Brown. It is found in Australia as far south as Port Denison, and is common at Trinity Bay and on the Johnstone River. 
133.-Cinnyris aspasie, Less., Voy. Coq. Zool. I., p. 676, No. 100. pl. 30. fig. 4 (1826); Shelley, M.on. Cinnr., pl. V., fig. 2.

Specimens of this beautiful Sun-bird were obtained by Morton on the Laloki River, in habits and actions it closely resembles the Australian Sun-bira, $C$. frenata, S. Mull ; builds the same kind of nest, and lays two to four eggs, white, with small blackish dots on the larger end.

This species was by no means common. On comparing it with those obtained by the Rev. George Brown at the Dule of York Islands,* I find it smaller in all its measurements, and the males from Port Moresby have a more violet-purple tint on the throat; the wings are browner, but this may be from immaturity; the tail is shorter, and the bill longer and narrower. From Captain G. E. Shelley's excellent monograph, I take the Port Moresby bird to be $C$. aspasia, of Lesson; and those from the Duke of York Islands I should take to be $C$. aspasioides, were it not for the lilac purple tinge on the throat; but the Duke of York birds have more of a steel-blue tinge than those from Port Moresby. The following are the measurements of a male from each locality :-

\begin{tabular}{|c|c|c|c|c|c|c|c|c|c|}
\hline \multirow{2}{*}{\multicolumn{6}{|c|}{ Total length from nostril to tip of tail }} & \multicolumn{3}{|c|}{$\begin{array}{l}\text { Duke of York } \\
\text { Islands. }\end{array}$} & \multirow{2}{*}{$\begin{array}{c}\begin{array}{c}\text { Port } \\
\text { Moresby }\end{array} \\
3 \cdot 7\end{array}$} \\
\hline & & & & & & & $3 \cdot 7$ & $\ldots$ & \\
\hline Culmer & & & $\ldots$ & $\ldots$ & $\ldots$ & .. & 0.82 & $\ldots$ & 0.94 \\
\hline Bill fro & $\mathrm{m}$ foreh & lead & $\ldots$ & $\ldots$ & $\ldots$ & $\ldots$ & $\cdot 85$ & $\ldots$ & 0.9 \\
\hline Width & at nostr & & $\ldots$ & $\ldots$ & $\ldots$ & $\ldots$ & 0.16 万, 0.2 우 & $\ldots$ & $0 \cdot 13$ \\
\hline & „, gape & & $\ldots$ & .. & $\ldots$ & $\ldots$ & $0.2 \delta, 0.26$ 守 & $\ldots$ & 0.28 \\
\hline Wing & & & $\ldots$ & .. & 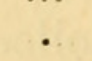 & $\ldots$ & $2 \cdot 45$ & $\ldots$ & $2 \cdot 45$ \\
\hline Tail & $\ldots$ & $\ldots$ & $\ldots$ & $\ldots$ & . & $\ldots$ & $1 \cdot 7$ & $\ldots$ & $1-5$ \\
\hline Tarsus & $\ldots$ & $\ldots$ & $\ldots$ & $\ldots$ & $\ldots$ & $\ldots$ & 0.63 & $\ldots$ & 0.6 \\
\hline
\end{tabular}

\section{ZOSTEROPID}

134.-ZOSTEROPS LONGIROSTRIS, $s p$. nov.

Adult Male. All the upper surface greenish yellow, wings and tail dark brown, outwardly margined with greenish yellow; under wing-coverts white, tinged with yellow on the shoulders; inner webs of the quills, except at the tips, white; all the under

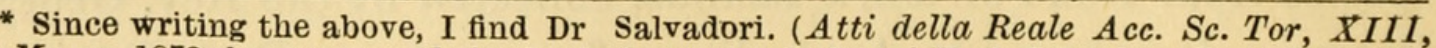
24 Marzo, 1878) has separated the birds from the Duke of York Islands, collected by Mr. Brown from the $C$. aspasice, of Lesson, and bestowed on them the name of Hermotimia (Cinnyris) corinna. 
surface yellow, brightest on the throat; abdomen and under tailcoverts slightly tinged with greenish yellow on the sides and flanks; lores yellow, narrow ring round the eye white, bill yellow, tinged with brownish at the tip ; feet olive grey.

Total length, 4 in.; wing, 2.5 ; tail, 1.45 ; tarsus, 0.7 in. ; bill from forehead, 0.7 in., from gape, 0.75 ; from nasal groove to tip, 0.4 .

Loc. Heath Island-(Broadbent).

\section{PLOCEID $A$.}

\section{5.-Munia Caniceps, Salvad.}

Donacola nigriceps (jwv.), Ramsay. P.L.S., N.S.W., vol. I., p 393.

In the Proceedings of the Linnean Society of N.S.W., above quoted, I described this species as the young of the followingM. nigriceps. Both are found in the Port Moresby district, frequenting the grassy slopes and ravines; but $M$. caniceps is less plentiful and was obtained further inland.

136.-Donacola nigriceps, Ramsay. P.Z.S. of N.S.W. I. 392 ; Sharpe op. cit. XIII., p. 501.

This species is allied to Donacola castaneothorax, of Gould, from N.S.W., but it is easily distinguished by the much darker head, and the upper tail-coverts. They were found plentiful all over the district; but appearing only at times in large floeks, and like many of the Australian species, frequenting the undulating grass lands and borders of the scrubs.

\section{Order COLUMB $巴$.}

TRERONIN A.

137.-Ptilopus gestroi, Salvad. and D'Alb.; Ann. Mus. Civ. Genov. VII. p. 834 (1875).

One specimen only from Mr. Broadbent's collection. Loc. Goldie River.

138.-Ptilopus iozonus, G. R. Gr., P.Z.S., 1858, p. 185.

This species was not found plentiful near Port Moresby. "Iris white, bill red at base, yellow at tip, legs red." 
139.-Ptilopus perlatus, Temm., Pl. Col. 559 (1835).

Two specimens from Morton's and Goldie's collection, and one from Broadbent's, of this fine species were all that were obtained -two adult males in full plumage and one young, in which the lake spots on the wings were of a much less intense tint. In the colouring of the tail and under coverts they agree more with Ptilopus zonurus of Salvadori (Prod. Ornith. Papuas. et Molucc., Ann. Mus. Civic. St. Nat. Genov. IX. (nota) p. 197).

\section{0.-Ptilopus cononulatus, G. R. Gr. P.Z.S. 1858, p. 185.}

This species appears to be very plentiful. Numbers were obtained, both during Mr. Goldie's first expedition and by Morton and Blunden during his second, on the Laloki River, feeding on berries and fruit of the native figtrees.

141.-Ptilopus pulchislus, Temm., Pl. Col. 564 (1835).

Only one specimen of this beautiful little dove was obtained; it was shot about twenty miles inland, near the Laloki River. Iris orange, bill yellow, feet purple.

142.-Ptilopus auranitifrons, G. R. Gr. P.Z.S. 1858, p. 185.

Salvad. Ann. Mus. Civic. Genov. IX., p. 197.

This appears to be also a scarce species, only one was obtained by Mr. Goldie.

143.-Ptilopus rivolir, Prevost; Knip. Pig. II. pl. 57.

I believe I am correct in assigning a large collection of whitechested Ptilopi before me to this species; they agree very well with $P$. rivolii, from the Duke of York group. The rose-purple of the breast is connected with the white chest band, but in some it is absent altogether, or there is visible merely a trace of this color. The white feathers of the chest are crossed with a curved bar of lemon-yellow near the tip, which gives a decided tint of yellow to the whole band; this yellow tint is also observable in the Duke of York specimens, when fresh, but by degrees it fades out. Mr. Goldie's and Broadbent's collection contained a large series, males, females, and young, from Teste Island. The young are of a uniform green, having only the lower part of the 
abdomen, under tail-coverts, and crissum, yellow; this would seem to separate them from $P$. prasinorrhous, of Dr. Gray; but I think this last species is founded only on an immature male of P. rivolii. P. strophium of $\mathrm{Mr}$. Gould appears to be much the same in plumage, but larger. The rose-purple on the chest is only attained by adult birds, many in the series being without it. I am inclined to look on $P$. rivolii, $P$. strophium, and $P$. prasinorrhous as mere varieties of one and the same species.

Hab. Deboyne Island, Teste Island, Cloudy Bay, Blunden River, \&c.

I can find but little, if any, difference between this species and P. bellus, of Sclater-except it be in the extent of red on the front. The yellow of the breast fades out in dried skins; the red on the fore part of the head extends to opposite the iris.

Total length, 9 in.; wing, $5 \cdot 1$ in.; tail, $3 \cdot 1$; tarsus, 0.83 ; bill, from forehead, 0.9 ; bill, from gape, $1 \cdot 1$.

144.-Ptilopus superbus, Temm. Ramsay, P.Z.S. 1876, p. 114; Gould, Handbook Bds. Aust. II, p. 108.

Several specimens were obtained by Mr. Goldie during his first and second expedition, and by Mr. K. Broadbent; they are quite the same as the Queensland specimens.

145.-Megaloprepia poliura, Salvad. Anr. Mus. Civic., Nat. Hist. Genova XII, (1878), p. 426.

Megaloprepia puella, Ramsay, (nec Less.), P. Lin. Soc. N.S.W. I, p. 394; id III, p. 103.

One of the most common species, taking the place of $M$. assimilis and $M$. magnifica, and differing from $M$. puella, of Lesson, in having the tail below grey.

146.-Carpophaga mulleri, Temm., Pl. Col. 566 (1835).

This fine species appears to be plentiful, the collection contains many specimens. The sexes are alike in plumage, and travel about in pairs, feeding on various berries and wild fruits.

147.-Carpophagu zoem, Less., Voy. Coq. Zool. Atlas, pl. 39 (1826).

This appears to be a rare species, as only one or two were obtained during the expedition; "iris white, bill black, feet 
purple-red" (K. B.) ; latterly Broadbent obtained several specimens far inland on the mountain ranges.

148.-Carpophaga, PInon, Quoy. and Gaim. Voy. de l'Uran. Zool., p. 118, pl. 28 (1824).

This fine pigeon proved to be one of the most plentiful; they were found associating in flocks of eight to ten in number, and were often found feeding in the native fig trees in company with $M$. spilorrhoa and $P$. coronulatus.

149.-Carpophaga van-wyckil, Cass., Proc. Acad. Philad, 1862, p. 320 .

A large number of this species were obtained on the south-east. end of the island, on Deboyne Island, and at Bramble Haven.

I find no difference between these and those from the Duke of York Islands.

150.-Carpophaga (Globicera) pacifica, Gm.; Salvadori, Att. della Reale Accad, Sc. di Torino XIII, 24, Gennaio (1878).

Several specimens, agreeing well with Dr. Salvadori's description.

Loc. Teste Island, South East Cape, \&c, (Goldie, Broadbent, Blunden.)

151. -Carpophaga rufigaster, Q. et Gaim., Voy. Astrol. p. 245, pl. 27, (1830).

C. rufiventris, Salvad., Ann. Mus. Civic. di St. Nat. Gen. IX, p. 201.

One specimen only obtained by Broadbent, 40 miles inland.

The figure in the Voyage de l'Astrolabe is not good, and without the description would be unrecognisable; the rump and upper tail-coverts should be of the same tint as the basal twothirds of the tail of a rich bronzy purple. "Iris, skin round the eye, and feet red; legs black," (K.B.).

152.-Mrristicivora spilorrhoa, G. R. Gr., P.Z.S., 1858, p. 186.

One of the most common species; found also all over the islands in Torres Straits in immense flocks, where, at night, they frequently roost in the mangroves in such numbers as to whiten 
the tops of the trees. They are found as far south as Port Denison. I believe the species found on New Ireland and Duke of York Islands to be M. luctruosa (or M. bicolor); however, it is certainly not the same as that from Australia, which must retain Gray's name of spilorrhoa. Eggs, two in number-white, oblong. Length 1.8 in., breadth 1.25 in. (From K. Broadbent.)

\section{COLUMBID $\nexists$.}

\section{3.--Ianthemas albogularis, $B p$.}

Ianthænas rawlinsoni, Sharpe; Nature, Aug. 17th, 1876.

This beautiful species, first obtained by Messrs. Broadbent and Petterd during Mr. Stone's expedition, seems still to be rare; it was only met with on one or two occasions. Morton obtained one, and I think a bird in Mr. Goldie's collection may also be referred to this species.

154.-Reinwardtena reinwardtit, Temm. Pl. Col., 248 (1825);

Salvad. Ann. Mus. Civic. Genov. vol. IX., p. 203 (1876-7).

Two specimens, adult male and female, from Broadbent's collection, obtained in the mountain scrubs, about forty miles inland from Port Moresby. "Iris and skin round the eye and the base of the bill red, tip of bill black, legs and feet red." (K.B.).

155.-Macropygia amboinensis, Linn. Syst. Nat. I., p. 286, n

38 (1766); Salvad. Ann. Mus. Civic. St. Nat. Genov. XII., 431.

Found frequenting the more dense parts of the scrubs, on the banks of the Laloki River. I have seen specimens from the Aru (?) Islands, Hall Sound, and the Duke of York Islands.

\section{Family GOURID Æ.}

156.-Geopelia humeralis, Temm. Trans. Linn. Soc. XIII., p. 128 (1821).

One specimen only obtained.

157.-Geopelia placida, Gould. Handbl. Bds. Aust. II., p. 145,

Very common everywhere in the more open parts of the country; usually found in pairs or small troops of four to six in number. I find no difference between the present specimens and those from Rockingham Bay. 
158.-Chalcophaps Chrysochlora, Wagl., Syst. Av. Columba sp. 79 (1827).

Common in the scrubs; found feeding on the ground. The plumage is of a slightly darker tint than the New South Wales individuals.

159.-Chalcophaps stephani, Pucher and Jacq. Voy. au Pôle. Sud. Zool. III., p. 119 (1853).

Not common. On comparing the Port Moresby specimens with those obtained by Rev. George Brown on Duke of York Island, I found the former of a much deeper tint both on the back and breast. The young are of a dull blackish brown above, the tips of the wings, wing-coverts, and scapularies margined with rufous; a tinge of rufous on the front and sides of the head; the under surface is of a slaty grey on the centre of the chest and abdomen, on the remainder blackish slate color; the tips of the feathers rufous on the chest.

\section{0.-Chalcophaps Jobiensis, Schleg.}

Chalcophaps margaritæ, Salvad. and D'Alb. Ann. Mus. Civ. Gen. VII, p. 836 (1875).

This beautiful species appears to be rare both at Port Moresby and elsewhere on the South Coast. Its range also extends on to New Ireland and Duke of York Island.

161.-Goura albertisi, Satvad. Atti. R. Ac. Sc. Tor. IX., p. 680. t. VII. (1876).

During Morton's stay at the Laloki River this magnificent bird was found frequenting the scrubs on the banks of the river in immense numbers, sometimes flocks of from ten to thirty in number were met with. They frequent the ground under the native figtrees, and other berry-bearing trees and shrubs, feeding on the fruits knocked down while other species of pigeons and doves are feeding above them; when disturbed they betake themselves to the lower branches of some neighbouring tree, from whence they are easily shot. During the heat of the day they prefer the more dense parts of the scrubs, where, perched 
upon some low branches, they may be seen preening and cleaning their feathers. On one occasion a small troop was met with on a dry sandy part of a scrub, dusting themselves like barn-door fowls in the sand. The crest, which sometimes obtains an expanse of 8 to 9 inches, seems to be immovable, always being carried in the same position. During September to Dcember, before the severe drought had broken up, the Gouras were so plentiful, that nearly two hundred of these fine pigeons were shot. Like other species of Goura, the gizzards of all examined contained one very large pebble, frequently of quartz, the largest obtained being about $1 \frac{1}{2}$ inches iu diameter. The natives of Port Moresby prize these pebbles very highly, wearing them suspended round their neck, rolled up in a leaf, as a charm, believing that this insures success in hunting.

Hab. Cloudy Bay, Blunden River, the Laloki and Goldie Rivers, \&c.

\section{CALEENADID平.}

162.-Calenas nicobarica. Linn. Syst. Nat. I, p. 383, n. 27 (1766) Salvad. Ann. Mus. Civic Genov. vol. IX, p. 208.

Large numbers of this fine pigeon were obtained on Deboyne Island and the adjacent islands. There is no difference between these individuals and those obtained by the Rev. George Brown on New Ireland and Duke of York Islands.

\section{GALLIN Æ.}

\section{MEGAPODID $\AA$.}

163.-Megapodius du-perreti, Less. Salvadori and D'Albert, $t$. $c$. p. 838 ; Ramsay, op. cit. I., p. 394; id op. cit. III. p. .

This is the common species, usually found in the scrubs on the banks of the Laloki River. The mounds resemble those of the Queensland $M$. tumulus, being heaps of leaves and debris scratched together to the height of about four feet and about ten feet diameter at the base. Eggs of a rich ocraceous or pinkish brown, $3 \cdot 2$ in length by 2.06 in breadth. 
164.-Talegallus fuscirostris; Salvadori, Ann. Mus. Civic. Genov. IX., p. 334.

Megapodius cuvieri, Less. Ramsay, P.L.S., N.S.W., I., p. 394, id. vol. II, p. 112.

This New Guinea species is about the same size as the Australian Talegalla. The eggs are of the same shape and form, and of the same color as those of all the species of Megapodius that have come under my notice. The eggs of the Talegalla proper, are of a pure white, and different in texture from those of the genus Megapodius.

This species was by no means plentiful, only a few specimens being secured.

\section{PERDICID $\nexists$.}

165.-Srnoicus cervinus, Gould. Bds. Aust. Handbook, II., p. 195.

This species is not uncommon in the grassy islands in the Straits, and was also procured near Port Moresby by Mr. Goldie, Morton, and Broadbent, The eggs are five to seven in number, creamy white, with minute dots of brown. Length 1:2 in., breadth 0.93 in.

\section{Order GRALLA.}

IBID丑.

166.-Numenius cranopus, V.; Gray, Handlist Birds, III., p. 42.

One specimen only obtained to the south-east of Port Moresby, at Kerapoona, Hood's Lagoon.

167. -Numenius uropygialis, Gould. Bds. Aust., fol. Vol. VI, pl. 43.

One specimen from Kerapoona.

CHARADRIID $\AA$.

168.-Lobivanellus miles, Bodd.

Several specimens, some from the Laloki River, others from the lagoon, near Boiara. 
169.-Squatorola helvetica, L. ; Gray, Handlist of Birds, III, p. 13.

One specimen only, from Port Moresby.

170.-Agialitis geoffroyi, Wagler, Syst. Av. Char., sp. 19.

Two specimens obtained at Kerapoona, or Hood's Lagoon, near the sea beach.

171.- A Agialitis hiaticula, Linn. Syst. Nat. I, p. 253.

Several specimens of both sexes, adults and young, in various stages of plumage, shot on the Laloki River, I can find no material difference between these and the European examples of A. hiaticuba, except in the greater extent of white on the forehead and on the outer two tail feathers.

\section{SCOLOPACID平.}

\section{2.-TRInga CRassirostris, Temm.}

Schœniclus magnus, Gould. Bds. Aust., fol. Vol. VI., pl. 33. This species was found abundant on all the low islands in Torres Straits.

One specimen, from Boiara.

173. -Actitis hypoledous, L. Gray, Handlist Bds., III, p. 46 ; Gould, Bds. Aust., fol. vol. VI, pl. 35.

One specimen, from T'este Island, and one from Boiara.

174.-Gambet'́ta pulverulentus, Mull.

Totanus griseopygius, Gould. Bds. Aust., fol. vol. VI, pl. 38.

One skin only obtained from East Cape.

\section{RALLID $A$.}

175.-Rallina tricolor, G. R. Gray, P.Z.S. 1858. p. 188 ; Ramsay, P.Z.S., 1875, p. 603 ; Gould, Supp. Bds. Aust. fol. Vol. $I, p l .78$.

One specimen was obtained by Mr. Goldie on the Laloki River.

176.-Porphyrio melanopterus, Temm.

"Red-bills" were found common, both on the banks of the Laloki and onthe shores of a lagoon near the river. 
177.-Gallinula tenebrosa, Gould. P.Z.S., pt. XIV., p. 20. (1878).

I find the collection contains a single example, which, I believe, is referable to this species; it was shot on the edge of a small lagoon near the Laloki River.

178.-Galdinula ruficrissa, Gould. Suppl. Bds. Aust. Vol. I. pl. 79.

One specimen only obtained.

\section{PARRID无.}

179.-Parra NOve-GUine, Ramsay. In lit. and Mss. Notes, Feb., 1878.

A fine series of this species, which, I believe, has hitherto been confounded with Parra gallinacea, Temm.

I transcribe, from my note-book of above date, the following description of this species which was first obtained by $\mathrm{Mr}$. J. H. Shaw, who accompanied Mr. Goldie, at a lagoon, fifteen miles inland from Boiara, and about twenty-five miles west of Port Moresby.

Adult Male. Total length, 7 in.; wing, 5 in. ; tail, $1 \cdot 7$; tarsus, $2 \cdot 1$; tibia, 3 in. ; hind toe, 1 in. ; its nail, $2 \cdot 7$; expanse of foot and nails, 7 in.; mid toe, $2 \cdot 15$; its nail, 0.9 ; outer toe: 2.35 ; its nail, 0.8 : inner toe, 1.9 ; its nail, 1 in; bill, from the eye, 1.25 ; from gape, 1 in.; length of comb from nostril to hinder margin, 1.15 ; its width, 0.65 ; its height, 0.3 (in dry skin). Color, bright reddish-orange (probably deep reddish flesh color in living birds). Bill, black at the tip, yellowish-red at the base ; legs and feet, olive green. A small spot at the base of the bill, the crown of the head, nape, and back of the neck, interscapular region, back, upper tail-coverts, tail, breast, and sides, flanks, under wing-coverts, and both the upper and under surface of the wings, as well as the primaries and the secondaries, deep black; median wing-coverts and scapularies very dark rich olive-brown, with a slight metallic tinge of greenish and purple gloss. Abdomen and under tail-coverts white; chin, throat, sides of the head and neck, and the upper part of the chest, white; along the 
sides of the head, and extending over the ear-coverts and in a narrow line down the side of the neck, separating the black of the upper from the white of the nnder side, is a stripe of a light glossy orange tint, whch extends in a band of the same color across the chest, margining above the jet black of the breast. The female is about one-fifth larger in size.

Mr. Shaw informs me that this species was rather plentiful at these lagoons, but, nevertheless, very shy ; and as the water was deep, and abounding in crocodiles, only those which were shot dead near the margin were obtained. They were found walking on the leaves of a species of Nymphea, and in habits closely resemble the Parra gallinacea of New South Wales.

The young have the crown of the head rufous as in the New South Wales species.

\section{HERODIONES.}

Family ARDEID A.

180.-Butoriodes Javanica, Horsf.; Sharpe, Journ. Linn. Soc. Zool. XIII, p. 320 ; Ramsay, List. Aust. Bds. sp. 628 ; Gould, Handbook Bds. Aust., II, sp. 561.

A specimen of this bittern was obtained on the Laloki River. It does not differ in any way from the Cape York and Queensland birds of the same species. It was the only one seen during the expedition, but probably the mangrove flats, where this species loves to dwell, were not closely examined. In New South Wales this species is by no means rare; they are found breeding in the mangroves on the Hunter and Clarence rivers ; and are common in similar situations at the mouth of the Herbert River. The nest is a scanty structure of a few dry sticks, placed crosswise on a horizontal bough; the eggs two to four, occasionally five in number, of a beautiful greenish-blue, about the size or a little smaller than the eggs of the common domestic fowl.

181.-Butoroides mlavicollis, Gould. Bds. aust. fol. Vol. VI, pl. 65.

One specimen only. Laloki River. 
182.-Tigrisoma heliosyla, Less. Voy. Coq. pl. 44; Sharpe, Journ. Linn. Soc. Zool. XIII., p. 321.

Mr. Goldie succeeded in obtaining three fine specimens of this beautiful bittern during his excursions about Port Moresby. In every instance, I am informed, they were found sitting on the thicker branches of large trees overhanging or near to the water.

183.-Nycticorax caledonicus, Lath. Gould, Bds. Aust. Handbook, II., sp. 557 ; Ramsay, List of Aust. Bds., sp. 624.

The Nankeen night-heron is not very plentiful in the Port Moresby district, but those specimens obtained are undoubtedly the same as the New South Wales birds, nor can I find any important differences in those from the Duke of York Islands.

184.-Herodias garzetta, Linn. Gould, Bds. Aust. Handbook II., sp. 552.

Specimens, which I refer to this species, were observed on the Laloki River; but only a few were obtained during the trip.

\section{5.-Demiegretta sacra, Gmel.}

The common white reef heron, plentiful on all the reefs at low water throughout the Straits and South East Coast. The Australian Museum possesses a very fine series of this species in various stages of plumage.

186.-Mycteria australis, Gould.

Several specimens of this fine bird were observed, but were too wary to admit of a near approach.

\section{Order ANSERES.}

Family ANATID $Æ$.

187.-Tadorna radjaH, Temm.

This fine species of wood duck seems plentiful all along the South Coast. Eggs obtained from the natives are of a creamy white. Length, 2 in; breadth, $1 \cdot 6$ in. 
188.-Dendrocygna guttata, Forsten; Salvad. and D'Alb. t.c. p. 839 ; Salvad. t.c. p. 49 ; Sharpe, t.c. p. 505, Ramsay, P.L.S. N.S.W., II, p. 395.

This is a common species on all the rivers and lagoons near Port Moresby. They breed in holes in the trees. The young attain the spots on the flanks at an early age, probably after the first month.

189.-Dendrocygna vagans, Eyton; Salvad., op. cit. IX, p. 49 ; Sharpe, op. cit. p. 505.

This species was not found to be so plentiful as the preceeding; habits the same.

Loc. Laloki River.

190.-Anas castanea, Eyton; Ramsay, P.L.S., N.S.W., III., p. 115 ; Gould, Bds. Aust., fol. , vol. VII, pl. 11.

Tolerably plentiful on sheets of water of any extent, and found at times in the salt water marshes and mangrove flats at low tides.

191. - Anas supercibiosa, Gm. Gray, Handlist of B., III, p. 82;

Sharpe, t.c., p. 505.

Specimens, not in any way differing from our Australian birds of this species, were obtained on the Laloki River; also found occasionally on the marigrove flats and at Shaw's Lagoon.

\section{Order GAVIÆ.}

\section{LARID A.}

\section{STERNIN A.}

192.-Sterna anglica, Mont.; Saunders, P.Z.S., 187, p. Gelochelidon macrotarsa, Gould, Bds. Aust., Supp. fol. vol. I, pl. 81 ; Handbook, id. II, sp. 608.

One specimen obtained by Mr. Goldie during his trip to Coutance Island.

193 --Sterna bergeri, Lecht.; Gould, Bds. Aust. Handbook II, p. 394, sp. 601; Ramsay, List Aust. Bds., sp. 680.

Common throughout the Torres Straits. 
194.-Sterna antestheta, Scop.

Sterna panayensis, Gould, Handbook Bds. Aust. vol. II, p. 411. One specimen only from Port Moresby.

195.-Sterna melanauchen, Temm.; Saunders, P.Z.S. (1876), p. 661 .

Not uncommon in Torres Straits and at South Cape.

\section{Order PYGOPODES.}

Family PODICIPID $Æ$.

196.-PODICEPS NOVE-HOLLANDIA.

P. gularis, Gould; Bds. Aust. Handbook II, p. 513.

Two specimens only obtained, shot by Morton and Blunden on the Laloki River. These are the only individuals I have seen of this species from New Guinea.

\section{Order STEG ANOPODES.}

PELECANID $\AA$.

197.-Pelecanus conspicillatus, Temm.

Seen on several occasions, but none obtained.

198. - Plotus nove-Hollandie, Gould, Bds. Aust. Handbook II, sp. 657 ; Ramsay, List Aust. Bds., sp. 732.

Several specimens, obtained by Mr. Goldie and $\mathrm{Mr}$. H. Shaw while encamped at Shaw's Lagoon, fifteen miles inland from "Boiara," a village on the coast, about twelve miles to the north-west of Port Moresby. I have also seen a specimen from the Laloki River, obtained during Mr. Goldie's first expedition.

199.-Phalacrocorax melanoleucus, Vieill.

Only one specimen obtained, shot about fifteen miles inland from Port Moresby. 
200.-Tachypetes aquila, Linn.; Gould, Handbook Bds. Aust. II, p. 499 ; Ramsay, List Aust. Bds., sp. 743.

One specimen obtained on the sea coast at Kerapoona, sixty miles east of Port Moresby.

Common throughout the Straits.

201.-Sula cranops, Sundevall.

Sula personata, Gould; Handbk. Bds. Aust. II, p. 506.

This fine species is far from rare in Torres Straits, and was also met with on many of the small islands towards East Cape.

Species omitted from foregoing List.

202.-Eupetes GOLDiei, $s p$. nov.

Adult.-Front and crown of the head, from the culmen, the nape and hind neck, and all the upper surface of the body, upper tailcoverts, and two centre tail feathers, and the wings olive brown; shoulders and upper wing-coverts black, those nearest the scapulars brown on the outer webs, primary quills washed with black on the basal portion of their outer webs; a stripe of black from the nostrils, taking in the lores, eye, and upper part of the earcoverts extends to the side of the occiput, but does not extend round the back of the head; below this a stripe of pure white from the base of the lower mandible to the end of the earcoverts ; chin, throat, and chest black, bounded on either side from the chest downwards, by a stripe of rich chestnut, which widens out on the sides of the breast, and extends in a broad band to the flanks, central part of the breast, and the abdomen white, bounded on either side by a series of lanceolate black marks, which extend from the black of the chest, on either side, on to the outer webs of the under tail-coverts, but forming roundish spots in those feathers near the vent; under tailcoverts white, with a broad stripe of black on their outer webs; tail black, except the two centre feathers and the apical portion of the inner webs of the next two on either side, the two outer 
feathers (at least) on either side largely tipped with white; under wing-coverts white, mottled with black, under surface of the quills brown; bill black; legs and feet and nails (ut videtur) light brown.

Total length, about 9 in.; wing, 4 in.; tail, 4 in.; tarsus, $1 \cdot 3$ in. Bill, from forehead, 1 in. ; from gape, $1 \cdot 18$; from nostril to tip, $0 \cdot 6$.

Loc.-This very distinct and beautiful species was obtained by Mr. Goldie about sixty miles inland from Port Moresby.

The specimen has, unfortunately, been shot through the neck and much damaged; the black from the sides of the head may probably join, behind the white ear-coverts, to the black of the breast, the feathers are wanting in this specimen.

\section{3.-Plectorhyncha Stictocephalus.}

Pycnonotus (?) stictocephalus, Salvad.; Ann. Mus. Civ. St. Nat. Genov. 19, Oct., 1876-7.

Total length, 9 in ; wing, 4.6 in ; tail, 4.2 ; tarsus, 0.95 ; bill from forehead, $0.9 \mathrm{in}$, from gape, 1.05 , from nostril, 0.5 .

Bill horn brown, legs and feet blackish slate color. The whole of the upper part of the head, occiput and nape, blackish brown, each feather narrow, pointed, and laneolate, with the extreme tip white; sides of the face and ear-coverts dark brown, with a slight glossy tint; all the upper and under surface of the body, wings, and tail dull brown; the under wing-coverts, and inner webs of the quills of the wings and tail, on the under surface, washed with brownish buff; under tail-coverts dull white, with narrow brown shaft stripes; the shafts of the tail feathers above reddish brown. There is also an indication of a white stripe from the angle of the mouth to below the eye, but the throat and neck are in such a bad state that it is impossible to describe these parts correctly.

Loc., Goldie River.

$$
\text { 204.-Micreaca aLbofrontata, } s p \text {. nov. }
$$

A line from the culmen, to the crown of the head, and the occiput, blackish-brown; wings and tail blackish-brown, a little lighter 

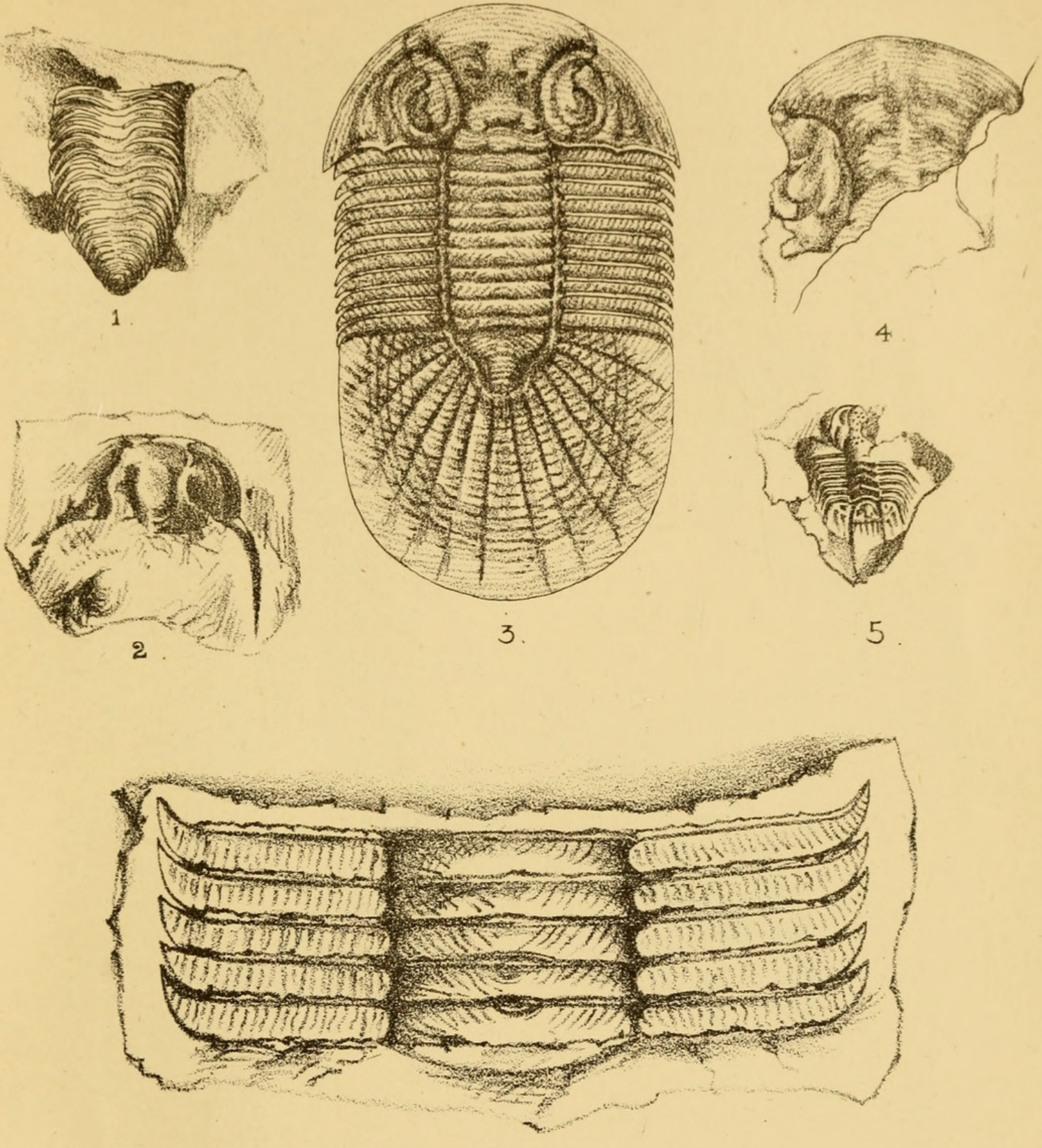

6

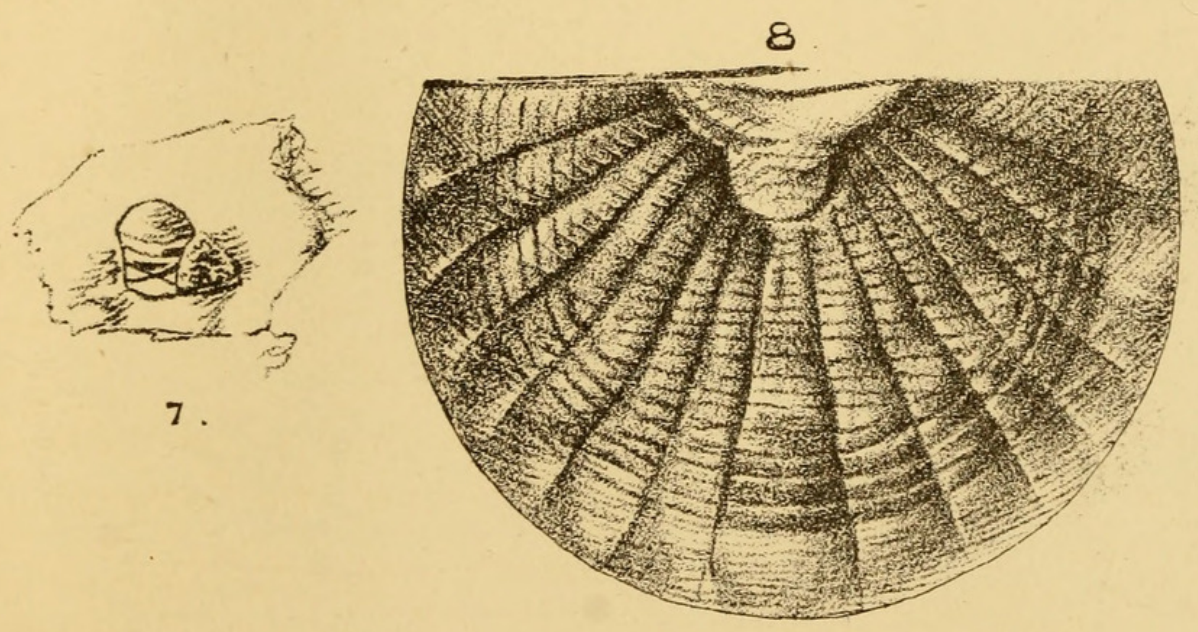

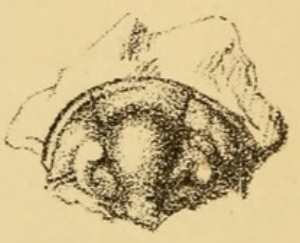

9 


\section{$2 \mathrm{BHL}$ Biodiversity Heritage Library}

Ramsay, Edward Pearson. 1879. "Contributions to the zoology of New Guinea. Parts I and II." Proceedings of the Linnean Society of New South Wales 3, 241-305. https://doi.org/10.5962/bhl.part.22241.

View This Item Online: https://www.biodiversitylibrary.org/item/30232

DOI: https://doi.org/10.5962/bhl.part.22241

Permalink: https://www.biodiversitylibrary.org/partpdf/22241

\section{Holding Institution}

MBLWHOI Library

\section{Sponsored by}

MBLWHOI Library

\section{Copyright \& Reuse}

Copyright Status: NOT_IN_COPYRIGHT

This document was created from content at the Biodiversity Heritage Library, the world's largest open access digital library for biodiversity literature and archives. Visit BHL at https://www.biodiversitylibrary.org. 